\title{
Conditions for resource-efficient production of biofuels for transport in Sweden
}

\author{
Carolina Ersson
}

Environmental Technology and Management Department of Management and Engineering Linköping University SE-581 83 Linköping

Sweden 
(C) Carolina Ersson, 2014

Conditions for resource-efficient biofuel production in Sweden.

Linköping Studies in Science and Technology. Licentiate thesis No 1662

ISBN: 978-91-7519-325-0

ISSN: 0280-7971

Printed by: LiU-Tryck, Linköping, Sweden, 2014

Distributed by:

Linköping University

Department of Management and Engineering

SE-581 83, Linköping

Sweden 


\section{Abstract}

Transportation has continued to increase worldwide and fossil-fuel dependency is strong which leads to a number of problems, e.g. increased emissions of green-house gases (GHG) and risks related to energy security. Biofuels have until now been one of the few renewable alternatives which have been able to replace fossil fuels on a large scale. The biofuel share in relation to the total use of fuel in the transportation sector is still small, but in many places in the world political targets are set to increase the share of renewable fuels, of which biofuels are supposed to be an important part. Within the European Union targets for renewable energy have been set, including within the transportation sector, where $10 \%$ shall come from renewable sources by 2020 according to the EU Renewable Energy Directive (EU RES). Biofuels also need to fulfill the sustainability criteria in the EU RES, to be regarded as renewable. Depending on how biofuels are produced their resource efficiency varies, and the differences in environmental and economic performance can for instance be significant.

The aim of this thesis is to describe and analyze conditions for a development towards increased and more resource-efficient production of biofuels in Sweden. The conditions have been studied from a regional resource perspective and from a biofuel producer perspective since it has been assumed that the producers are in possession of important knowledge, and potentially will play an important role in future biofuel development. The concept of resource efficiency used in this thesis includes an environmental and economic perspective as well as an overall societal dimension to some extent. The region of Östergötland in Sweden was used for the assessment of the resourcefocused biofuel potential for the year 2030, where two scenarios based on assessments regarding socio-technical development in relation to regional resources were used. The scenarios were based on semi-structured interviews with biofuel actors, literature studies and information from experts in the field. In the EXPAN (Expansion) scenario a continued development in line with the current one was assumed, but also an increased availability of feedstock primarily within the agricultural and waste sectors (also including byproducts from industry) for biofuel production. In the INNTEK (Innovation and Technology development) scenario greater technological progress was assumed to also enable the use of some unconventional feedstock besides increased available arable land and improved collection/availability of certain feedstock. Biomass feedstock from four categories was included in the potential: waste, agriculture, forestry and aquatic environments. One important feedstock which was not included in this study, but which is often included in studies of potential, is lignocellulosic material from the forest. This choice was also supported by the regional actors who judged it as less probable that there will be any large-scale use of such feedstock for biofuels in this region within the given timeframe. Regarding arable land available for biofuel production a share of $30 \%$ was assumed at maximum in the region, of which $15 \%$ is already used for cereal production for ethanol fuel. On these additional $15 \%$ assumed to be available for biofuel production year 2030 , ley cropping for production of biogas was assumed in this study. Aquatic biomass is often not included in biofuel potentials. Here, algae were assumed to be a potentially interesting substrate for biogas production since harvesting algae in for instance the Baltic Sea could be seen as a multifunctional 
measure, i.e., contributing additional environmental benefits such as reducing eutrophication. Based on the assumption that the energy need in the transportation sector will be the same in 2030 as in 2010, up to $30 \%$ could be substituted with biofuels in the EXPAN scenario and up to $50 \%$ in the INNTEK scenario, without seriously conflicting with other interests such as food or feed production. In the study of potential, production systems for biogas production were prioritized since such systems were judged to have a large potential for resource efficiency. This is because they have a big capacity to utilize by-products and waste as feedstock, and also because they can contribute to closing the loops of plant nutrients, seen as an important goal in society, if the digestate is returned to arable land.

The utilization of by-products and waste however in many cases requires cooperation between different actors in society. Within the research field of industrial symbiosis, cooperation regarding material and energy flows is studied from different perspectives, e.g. how such cooperation between actors evolves and to what extent such cooperation can contribute to improving the environmental and economic performance of systems. Both these perspectives are interesting in relation to biofuels since production often involves a large number of energy- and material flows at the same time as resource efficiency is important. How the producers organize the production when it comes to feedstock, energy, by-products and products and what influences this is therefore interesting to study. In this thesis four biofuel producers of three different biofuels (ethanol, biodiesel and biogas) on the Swedish market were studied, focusing on how they organize their biofuel production in terms of e.g. their material and energy flows, and how they intend to organize it in the future. The study is based on semi-structured interviews with the biofuel producers as well as literature studies. In all the cases, a number of areas of material and energy flow cooperation were identified and it could also be concluded that there had been some change regarding these patterns over time. Looking into the future a clear change of strategy was identified in the ethanol case and partly also in the biodiesel case where a development towards improved valorisation and differentiation of by-product flows was foreseen. If such a "biorefinery" strategy is realized, it can potentially improve the economic viability and resource efficiency in these biofuel producers. In the biogas cases, instead a strategy to lower the costs for feedstock through the use of lower quality feedstock was identified. This strategy also has a potential to increase economic viability and improve the resource efficiency. However, the success of this strategy is to a large extent dependent on how the off-set of the biofertilizer can be arranged regarding the economic challenges that the biogas producers' experience, and yet no strategy for implementation regarding this was identified. The EU Renewable Energy Directive was mentioned in relation to most cooperation projects and therefore regarded as an important critical factor. All of the studied companies also struggle to be competitive, for which reason the importance of the direct economic aspects of cooperation seems to increase. 


\section{Sammanfattning}

Transporterna i världen ökar kontinuerligt och det fossila beroendet är fortsatt stort vilket medför flera problem, bl. a. ökade utsläpp av växthusgaser och en osäkerhet kring framtidens energiförsörjning. Biodrivmedel har hittills varit ett av de få förnyelsebara alternativ som kunnat ersätta fossila drivmedel i stor skala. Andelen biodrivmedel av den totala bränsleanvändningen inom transportsektorn är dock fortfarande liten, men på många håll i världen finns nu politiska mål för att öka andelen förnyelsebara drivmedel av vilka biodrivmedel förväntas utgöra en viktig del. Inom EU har mål för förnybar energi satts upp bl. a. inom transportsektorn där $10 \%$ skall komma från förnybara energikällor senast år 2020 enligt EUs förnybarhetsdirektiv. Biodrivmedel måste dessutom, om de ska räknas som förnyelsebara, uppfylla direktivets hållbarhetskriterier. Beroende på hur biodrivmedel produceras är de olika resurseffektiva, med exempelvis betydande skillnader avseende miljömässig och ekonomisk prestanda.

Syftet med den här avhandlingen är att beskriva och analysera förutsättningarna för en utveckling mot ökad och mer resurseffektiv produktion av biodrivmedel i Sverige. Förutsättningarna har studerats med ett regionalt resursperspektiv samt från ett biodrivmedelsproducentperspektiv eftersom producenterna sitter på viktiga kunskaper och sannolikt spelar en betydande roll för den framtida utvecklingen. Resurseffektivitetsbegreppet som används i den här avhandlingen inkluderar ett miljömässigt och ett ekonomiskt perspektiv liksom ett övergripande samhälleligt perspektiv. När det gäller ett regionalt resursperspektiv har Östergötland använts för att med hjälp av två scenarier för år 2030 ta fram en biodrivmedelspotential utifrån en bedömning av en socio-teknisk utvecklingspotential i förhållande till regionala resurser. Scenarierna togs fram med hjälp av semistrukturerade intervjuer med aktörer i branschen, litteraturstudier och i vissa fall med hjälp av sakkunniga. I scenario EXPAN (expansionsscenario) antogs en fortsatt teknikutveckling i linje med den hittills-varande och en samtidig ökning av tillgängligheten av potentiella resurser inom framförallt jordbrukssektorn och avfallssektorn (inkluderat också restproduktsresurser inom industrin) för biodrivmedelsproduktion. I scenario INNTEK (Innovations och teknikutvecklingsscenario) har utöver ytterligare antagen tillgänglig jordbruksmark också större tekniksprång antagits som möjliggör användning av icke konventionella råvaror för biodrivmedelsproduktion, samt förbättrad insamling/tillgängliggörande av vissa råvaror. I potentialen har biomassa från fyra olika sektorer inkluderats; avfall, jordbruk, skogsbruk och akvatiska miljöer. En viktig biomassaresurs som inte inkluderats i denna potentialstudie, men som vanligen inkluderas i potentialstudier, är lignocellulosarika material från skogen. Detta var ett val som också stöddes av de regionala aktörerna som i den här studien bedömde det som mindre sannolikt att någon storskalig användning av sådana råvaror kommer att finnas i regionen inom den aktuella tidsramen. När det gäller jordbruksmark som kan utnyttjas för bioenergiproduktion så har en andel på 30\% antagits, varav 15\% redan idag utnyttjas till spannmålsodling för produktion av etanol. På de ytterligare 15\% som antas kunna tas i anspråk för biodrivmedelsändamål år 2030, har vallodling för biogasändamål antagits i denna studie. Akvatisk biomassa ingår ofta inte $i$ bioenergipotentialstudier, men har inkluderats här eftersom alger skulle kunna vara ett intressant 
substrat för biogasproduktion, men också för att algskörd i akvatiska miljöer skulle kunna ses som en multifunktionell åtgärd med ytterligare miljönytta som t.ex. minskad övergödning i Östersjön. Med antagandet att energibehovet inom transportsektorn blir lika stort år 2030 som år 2010, skulle upp till $30 \%$ av de fossila drivmedlen kunna ersättas av biodrivmedel i scenario EXPAN och upp till 50\% i scenario INNTEK, utan att större intressekonflikter skulle uppstå i förhållande till andra behov såsom mat eller foderproduktion. I potentialstudien har vidare produktionssystem för biogas prioriterats eftersom sådana system bedömdes ha stor potential när det gäller resurseffektivitet. Först och främst för att de har stor kapacitet när det gäller användning av restprodukter, men också för att de kan bidra till att sluta kretsloppet av växtnäringsämnen om rötresten återförs till åkermark.

Nyttiggörande av restprodukter och avfall kräver emellertid i många fall samarbete mellan olika aktörer i samhället. Inom forskningsfältet industriell symbios studerar man bl. a. hur samarbeten kring energi- och materialflöden mellan aktörer uppstår och i vilken utsträckning samarbetsgraden kan bidra till att förbättra miljöprestandan och ekonomiska prestanda i systemen. Dessa perspektiv är intressanta i förhållande till biodrivmedel eftersom produktionen av dessa är förknippad med ett stort antal energi- och materialflöden samtidigt som resurseffektiviteten är viktig. Hur biodrivmedelsproducenterna organiserar produktionen när det gäller råvaror, energi, biprodukter och produkter och vad som styr detta är därför intressant att studera. I den här avhandlingen studerades hur fyra svenska biodrivmedelsproducenter för tre olika biodrivmedel (etanol, biodiesel och biogas) på den svenska marknaden har organiserat sin produktion, med fokus på energi- och materialflöden, samt hur de planerar att organisera den framöver. Studien baseras framförallt på semi-strukturerade intervjuer med aktörerna samt litteraturstudier. I samtliga fyra fall kunde ett antal samarbeten kring bl.a. material och energiflöden kartläggas samt hur dessa förändrats över tiden. När det gäller framtiden kunde en tydlig strategiomläggning ses i etanolfallet och delvis $i$ biodieselfallet mot en valorisering och diversifiering av rest-/bi-produktflöden. Om denna "bioraffinaderistrategi" lyckas kan den bidra till bättre lönsamhet och bättre resurseffektivitet. I biogasfallen fanns istället strategier för att försöka sänka råvarukostnader genom att hitta råvaror av lägre kvalitet. Också denna strategi kan öka lönsamheten och förbättra resurseffektiviteten, men detta förutsätter att avsättningen av biogödsel också kan lösas på ett lönsamt sätt. Detta är en fortsatt stor utmaning för biogasproducenterna. En av de viktigaste kritiska faktorerna för de olika samarbetsprojekten var EUs förnybarhetsdirektiv som nämndes i samband med de flesta samarbetsprojekt och som här sågs som en miljömässig drivkraft. Också det långsiktiga byggandet av gröna varumärken verkar vara en drivkraft, åtminstone när det gäller vissa samarbetsprojekt. Samtliga biodrivmedelsproducenter kämpar idag med lönsamheten varför också de ekonomiska aspekterna kring samarbeten är mycket väsentliga. 


\section{Appended Papers and My contribution}

This Licentiate thesis includes two papers which have been realized in cooperation with my supervisors. Hence my contribution needs to be clarified in relation to each paper which is done in the following section.

\section{Paper 1}

Title: $\quad$ Biofuels for transportation in 2030: Feedstock and production plants in a Swedish county.

Journal: $\quad$ Biofuels, 4 (2013), 379-395.

Corresponding author: Carolina Ersson

Co-authors: Jonas Ammenberg \& Mats Eklund

Status: $\quad$ Published

Empirical data collection:

I conducted all the interviews as well as transcriptibed them. I also made the literature study and data collection for the biofuel assessment study with some guidance from my supervisors. The scenario building and most of the assumptions were done by me in collaboration with my supervisors.

Writing and analysis:

The writing was done in cooperation with my supervisors although I wrote the original drafts. Jonas wrote the introduction and had a major influence on the methodology chapter.

The paper is based on a project report written in Swedish by me with contribution from my supervisors Mats Eklund, Jonas Ammenberg and Jenny Ivner.

\section{Paper 2}

Title: $\quad$ Connectedness and its dynamics in the Swedish biofuel for transport industry

Journal: $\quad$ Manuscript submitted to Progress in Industrial Ecology

Corresponding author: Carolina Ersson

Co-authors: Jonas Ammenberg, Mats Eklund

Status: $\quad$ Unpublished manuscript 


\section{Empirical data collection:}

Two of the four interviews were conducted in cooperation with one of my supervisors while the other two were conducted by me alone. I transcribed all the interviews and made supplementary data collection. I also constructed the validation forms that were sent by e-mail to respondents and also contacted the respondents that did not respond by phone for validation.

\section{Writing and analysis:}

The analysis was made based on three questions constructed together with my supervisors. The writing has been done in cooperation with my supervisors although I wrote the original drafts. The introduction was written by Jonas Ammenberg and the section future studies was written by Mats Eklund and me. The figures have been constructed by me.

I have also presented the empirical material as an extended abstract at the ISIE Conference, Ulsan, South Korea, June 2013.

\section{Related Publications}

Ersson Carolina, Eklund Mats, Ammenberg Jonas, Ivner Jenny. Vision för biodrivmedel i Östergötland Tillgång på regionala råvaror och principer för en resurseffektiv produktion år 2030. Linköping University, 2012. Rapport LIU-IEI-R--12/0002-SE. 


\section{Table of Contents}

\begin{tabular}{l|l|l} 
ABSTRACT & III
\end{tabular}

SAMMANFATTNING V V

$\begin{array}{lll}\text { ACKNOWLEDGEMENTS IX } & \text { IX }\end{array}$

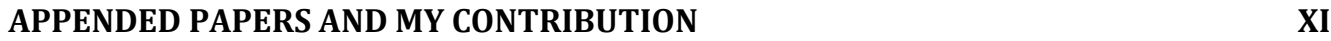

$\begin{array}{lll}\text { Related Publications } & \text { XII }\end{array}$

1 INTRODUCTION 1

1.1 Aim, research questions and scoping 3

$\begin{array}{ll}1.2 \text { Central concepts } & 4\end{array}$

$\begin{array}{lll}\text { 1.2.1 The concept of resource efficiency } & 5\end{array}$

$\begin{array}{lll}\text { 1.2.2 Other concepts of interest in this thesis } & 6\end{array}$

$2 \quad$ BIOFUELS AND RENEWABLE ENERGY IN SWEDEN 9

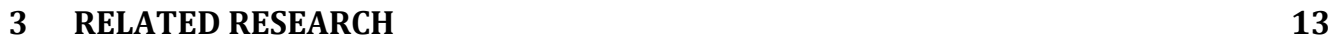

$\begin{array}{ll}3.1 \text { Biofuels } & 14\end{array}$

$\begin{array}{ll}3.2 \text { Industrial Ecology and Industrial Symbiosis } & 16\end{array}$

$\begin{array}{lr}3.3 \text { Business strategy } & 18\end{array}$

4 METHODOLOGY $\quad 21$

$\begin{array}{ll}4.1 \text { Overall research design and research journey } & 21\end{array}$

$\begin{array}{ll}\text { 4.2 Data collection } & 25\end{array}$

$\begin{array}{llr}\text { 4.2.1 Data collection RQ1 } & 26\end{array}$

$\begin{array}{llr}\text { 4.2.2 Data collection RQ2 } & 27\end{array}$

$\begin{array}{lr}4.3 \text { Analysis } & 28\end{array}$ 
$\begin{array}{llr}\text { 4.3.2 Analytical approach RQ2 } & 29\end{array}$

4.4 Reflections on methodological strengths and limitations 29

5 POTENTIAL FOR BIOFUELS FOR TRANSPORT IN ÖSTERGÖTLAND YEAR 2030 AND THE CHALLENGES OF IMPLEMENTATION 33

$\begin{array}{ll}5.1 \text { Feedstock potential } & 33\end{array}$

5.2 Biofuel potential in Östergötland $\quad 34$

5.3 Approaching the challenges of implementation 36

5.3.1 Need of new production plants 36

5.3.2 Integrated, resource-efficient \& multi-functional biofuel production systems 37

6 CONNECTEDNESS AND ITS DYNAMICS IN SOME SWEDISH BIOFUEL PRODUCERS 41

6.1 Business strategies, status and dynamics of connectedness in the ethanol company 42

6.2 Status of and dynamics in connectedness

$\begin{array}{ll}6.3 \text { Critical factors for connectedness } & 46\end{array}$

$7 \quad$ CONCLUSIONS $\quad 49$

8 FUTURE RESEARCH $\quad 51$

REFERENCES 


\section{Introduction}

The introduction aims at giving some background of this thesis as well as motivation for the research questions and aim which are introduced in this chapter.

Transportation is a crucial driver of economic growth and poverty reduction (World Bank, 2013) and our need for transport of people and goods in the world is continuously increasing. Transportation is moreover also expected to grow during the coming decades (U.S. Energy Information Agency (EIA), 2013). A major part of the energy used for road transport today is of fossil origin (International Energy Agency, 2011) which is problematic from an environmental point of view (e.g. climate change) and for many countries it is also an energy security issue. However in Europe these challenges have been met as an opportunity to create a smarter, more sustainable economy as outlined in the EU growth strategy (European Commission, 2014, European Commission., 2012, European Commission, 2011). The EU 2020 goals in the Renewable Energy Directive (EU RES, 2009) where targets for the share of renewable energy in the energy and transportation sector are set for all EU member states, are for instance part of this strategy. The transportation and energy sectors are by far the most important emitters of greenhouse gases (GHG) in Europe (Eurostat, 2014) which makes them important sectors regarding climate mitigation.

Some countries within the EU are well underway to increase the share of renewables in terms of the total energy supply, while the transportation sector is lagging behind with renewable shares of about $4 \%$ for most countries (Eurostat, 2013). Globally the share of renewable fuels for road transport is small and liquid biofuels account for the largest share, around $3.4 \%$ (REN21 Renewable Energy Policy Network for the 21st century, 2013). Biofuels are however expected to play an important role for the energy supply in the transportation sector for decades to come according to many energy forecasts and projections (OECD/FAO, 2012, BP, 2012, Igliński et al., 2012, Exxon Mobil, 2013). Biofuels encompass adequate chemical properties and can offer a type of energy source for transportation that societies require today, which puts them in a unique position in relation to other alternative renewable fuels available (Ponton, 2009).

The environmental benefits of using biofuels have been questioned however in the recent debate mainly due to the fact that life cycle assessment for some biofuels has shown GHG emissions comparable to fossil fuels (Martin, 2010). The GHG emissions are however largely dependent on the biofuel production system and the low reduction of GHG emissions of some biofuels can therefore not be generalized to all biofuels (Börjesson, 2009, Börjesson and Tufvesson, 2011). To secure the ambition to reduce environmental impact from the transportation sector by increasing the share of biofuels the European Renewable Directive (EU RES) also contains sustainability criteria, e.g. demanding a certain level of GHG reductions (EU RES, 2009). The possibilities to produce resourceefficient biofuels with good environmental performance differ between different biofuels and due 
to local prerequisites (Börjesson and Mattiasson, 2008, Börjesson, 2009), and cases found in literature show that there is a potential to reduce GHG emissions substantially with a beneficial biofuel production system (e.g. Martin et al., 2014).

If and how biofuels are produced is dependent however on the biofuel producing actors. As such biofuel production actors have an important role in the development towards more resourceefficient biofuel production. An interesting question to study is: How much biofuels can be produced? However it may be more interesting and important to ask: How much 'beneficial biofuels' can be produced from a resource efficiency and environmental performance perspective? Industrial ecology and especially the subfield of Industrial symbiosis are research fields addressing the necessity of resource-efficient material and energy handling in society and industry. Central in the concept of industrial ecology is the systems perspective and an important feature is the possibility to change focus within the system (Graedel and Allenby, 2010) where industrial symbiosis for instance focuses on possibilities and challenges for resource-efficient industrial production systems. This focus is relevant in relation to the biofuel industry, where the exchanges of by-products and energy have improved the environmental performance of biofuels substantially in some existing systems (Martin, 2013). Industrial symbiosis however often requires more in terms of cooperation than ordinary supply chain interactions, such as infrastructure for exchanges or long-term contracts which often makes implementation processes very long (Jacobsen, 2009). The biofuel industry in Europe is however surrounded by environmental policy frameworks aimed at sustainable biofuel production. There is also a market for environmentally and economically competitive biofuels, which is why the conditions and incentives for industrial symbiosis cooperation could be assumed to differ from other industrial contexts studied within the industrial symbiosis field. The conditions for industrial symbiosis in the biofuel industry could therefore also be of interest in relation to the industrial symbiosis research field.

Sweden is an interesting country regarding biofuels for transport for several reasons. Firstly the EU 2020 goal of $10 \%$ renewables fulfilling the sustainability criteria in the transportation sector has already been reached, $12.6 \%$ in 2012 (Regeringskansliet, 2013), and the political ambition is to reach further for which a national goal has been set - to have a fossil-independent vehicle fleet by 2030 . This in turn is supposed to be a step towards a fossil-free transport sector by 2050 (Ministry of Industry Employment and Communications, 2012). Secondly the market and production of biofuels for transport in Sweden is more diverse than in most places in Europe and worldwide due to the development of a system for biogas in vehicles (AEBIOM, 2009). This application has developed into large-scale applications and adds to the more well-established ethanol and biodiesel systems common in many places around the world (REN21 - Renewable Energy Policy Network for the 21st century, 2013). Thirdly Sweden has a history of long-standing political commitment to development of renewable energy which has led to a unique transformation of the energy system (Nilsson et al., 2004). 
The region of Östergötland is an interesting region regarding biofuel production since biofuel production systems with elements of industrial symbiosis and with acknowledged good environmental performance can be found there (cf. Martin and Eklund, 2011, Martin, 2010). These production systems have developed over time with continuous integration and adaptation to the local context which is why Östergötland can be considered a leading-edge county within Sweden (Eklund, 2010) and a hot spot of production facilities for biofuels with relatively large-scale, synergistic and mainly locally supplied facilities (Martin and Eklund, 2011).

Now with the background given in the introduction, the aim and the research questions (RQs) in this thesis can be introduced together with the scope of my research. Some of the concepts and terminology used will be further explained in the subsequent section, central concepts.

\subsection{Aim, research questions and scoping}

The aim of this thesis is to describe and analyze conditions for development towards increased and more resource-efficient biofuel production in Sweden.

To approach this aim two research questions have been formulated (RQ1 and RQ2) with associated sub-questions.

RQ1. To what extent could resource-efficient biofuels for transport substitute fossil fuels in a Swedish region in year 2030 ?

-How could regional biofuel potentials be assessed?

- How large is the biofuel potential considering different future scenarios and what is required in terms of biofuel production plants?

A geographical scope is necessary in order to be able to assess a biofuel feedstock potential domestic to an area. Data is often more easily available if this geographical scope is synchronized with administrative boundaries, such as a region e.g. Östergötland used here, since this is one of the aggregation levels of data used in Swedish statistics. However, for the realization of the potential these regional boundaries should not be considered absolute barriers. An optimal location for a biofuel plant could also be outside the boundaries with feedstock also from other regions.

The potential is also dependent on the time scope. The time perspective in this thesis should reflect the time perspective of the many political goals and targets set for renewable energy in Sweden and Europe, which is why the year 2030 was chosen in RQ1.

The potential to produce resource-efficient biofuels depends on the conditions decided by many different aspects such as policy framework, market, price and availability of feedstock, infrastructure, etc. Companies will respond to the present conditions as well as forecasted 
conditions by creating business strategies which could have a longer or shorter time perspective. Some of these business strategies will have an impact on the organization of the biofuel production and cooperation with other firms which could influence the environmental and economic performance of the biofuels produced. RQ2 was formulated as below.

RQ2. How and to what extent are Swedish biofuel producers developing towards resource efficiency?

- How are some existing Swedish biofuel producers organizing their biofuel production, e.g. their material and energy flows, and how has this changed over time?

- Which are their business strategies and how have they changed over time?

- What are the critical factors influencing the connectedness of the different biofuel producers?

In this thesis, existing biofuel production companies are seen as important informants regarding the conditions for resource-efficient production of biofuels.

The geographical scope in relation to RQ2 is extended, involving actors not only active in Östergötland but in several parts of Sweden. At each site, conditions are specific regarding for instance feedstock and energy supply while policy frameworks at the national level and to some extent also market conditions for the products are more alike.

The time perspective in relation to RQ2 was shorter, up to ten years, since companies normally have to adapt business strategies to the economic conditions which are often regarded as less stable than for instance technological conditions (Offermann et al., 2011). Further on, the intention of using the resource efficiency concept here was to include environmental aspects in a broad sense. However, in some parts mainly climate issues have been in focus.

\subsection{Central concepts}

In the section some central concepts used in this thesis are explained as the author wants readers to understand them in this particular context. 


\subsubsection{The concept of resource efficiency}

The most central concept in this thesis is the resource efficiency concept, which relates to the environmental, energy and economic perspectives of biofuel production systems. The economic perspective reflects the biofuel producers' perspective, but also the societal dimension, considering needs and resource management within a wider context (e.g. within a region). Resource efficiency in this thesis should thereby be understood as a broader concept than environmental performance, focusing on environmental and energy performance, the profitability of biofuel producers, and positive societal economic effects. In brief, to maximize the value added and minimize the negative impacts (cf. eco-efficiency)(Ehrenfeld, 2005). The two cases in Figure 1 conceptually illustrate how some aspects relevant for resource efficiency differs in a "linear case" compared to a more "synergistic" example. To summarize, resource efficiency is here assumed to increase in the following cases:

- Increased share of raw material of a lower value and/or with a lower environmental impact, e.g. increased share of secondary raw materials in the feedstock and/or using feedstock with increased land use efficiency (cf. Börjesson and Mattiasson, 2008, Fischer et al., 2010, Singh et al., 2011)

- Increased share of energy of a lower value and/or with a lower environmental impact, e.g. substitute electricity (high exergy) with heat (low exergy) or an increased share of renewable energy in the production system (cf. Börjesson, 2009, Martin, 2010, Martin et al., 2014)

- Increased value of the products (including by-products), via diversification and valorisation, without significantly changing the input of material or energy, alternatively improving internal efficiency and thereby increasing the output (cf. de Wit et al., 2010, Cherubini, 2010a, Martin et al., 2014)

The above mentioned features are considered to be the most important aspects, but also other aspects not included in the figure are also considered to impact resource efficiency to some extent in this thesis. Hence, in addition to what is illustrated in Figure 1, the resource efficiency is also assumed to increase if:

- Transportation becomes more efficient, via reduced transportation or a shift towards transportation having lower environmental impact (Berglund and Börjesson, 2006)

- The characteristics of the products are improved implying reduced environmental impact, or additional positive environmental effects, when they are used.

- Value is added alongside the product chain, in the form of functions, services or utilities e.g. improved agricultural practices (cf. Jokela, 2011, Ericsson et al., 2009).

The bullet points above reflect the multidimensional perspective which was considered important in relation to resource efficiency in biofuel production systems in this thesis. Even if it represents a broad perspective it should not be regarded as a complete list since there are always cases where 
other aspects could be influential. This conceptual frame-work defines resource efficiency in a broad sense and can be used to qualitatively monitor different production systems, or changes within production systems as well to highlight development within several areas of relevance, e.g. biofuels.

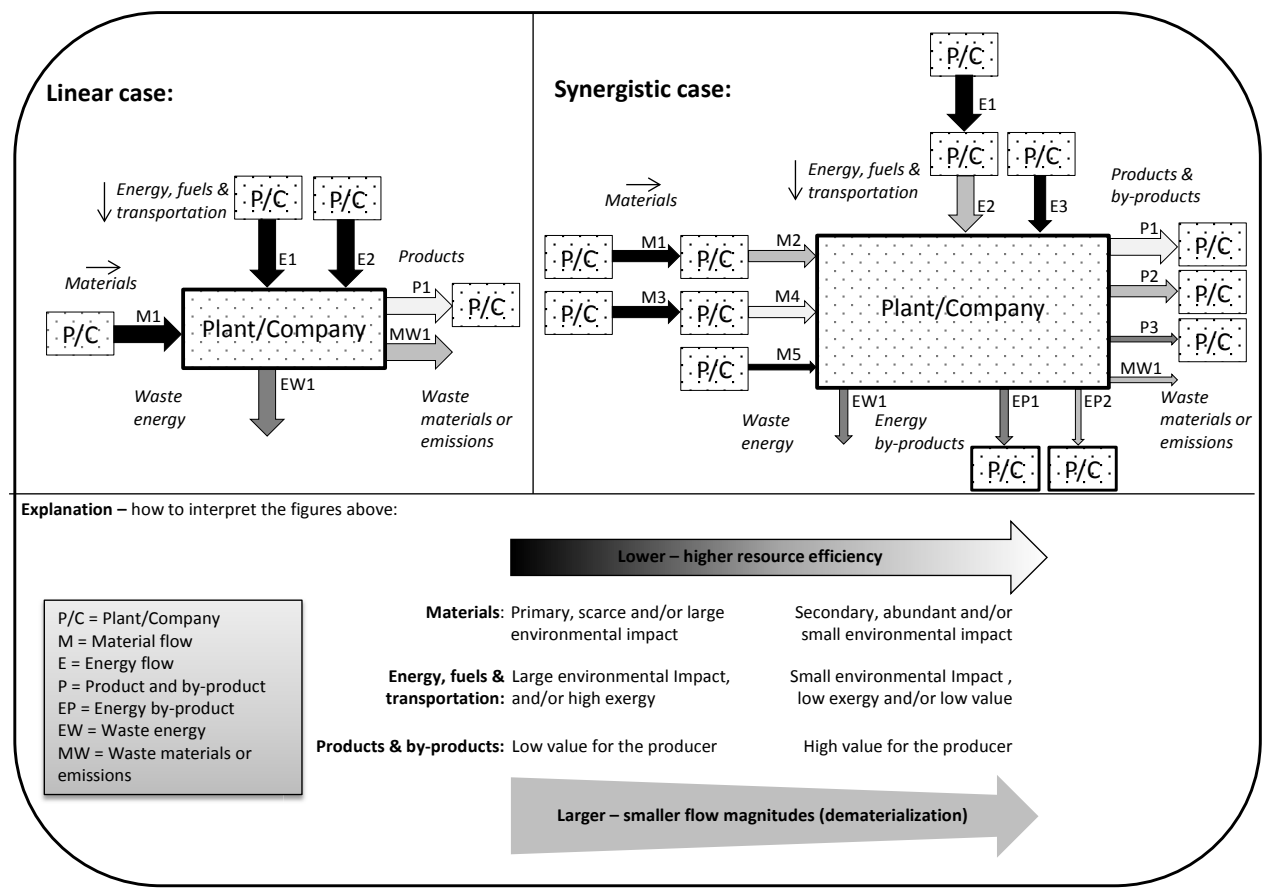

Figure 1. A schematic illustration of a linear and a synergistic production system (Paper 1).

The background of how and why the resource efficiency concept is used in this thesis will be further explained and clarified in chapter 4, Related Research.

\subsubsection{Other concepts of interest in this thesis}

Additionally some other concepts are used in this thesis which needs to be defined based on how they are used here.

Biofuels in this thesis refers to biofuels for transport which are energy carriers that can be used for the propulsion of vehicles, retrieved from biomass if not otherwise mentioned in the text. Biofuels will primarily refer to ethanol, biodiesel (here also including hydrotreated vegetable oil - HVO) and biogas in this thesis. 
Biofuel industry refers to the industrial production plants of the biofuels mentioned above.

Biofuel production systems refers not only to the biofuel production plants, but the whole life cycle involved in the production of a particular biofuel including for instance the supply of feedstock, energy, transportation and also the handling of waste and by-products.

Biofuel actor refers here to companies, organizations or societal institutions with a connection to biofuels.

Environmental performance of biofuels relates to the relative emissions and impact caused on the environment during their life cycle (cf. Martin, 2010).

Connectedness refers to collaboration between actors along the product chain of biofuels, where exchanges of material and energy are involved including both suppliers of material and energy and customers. Connectedness in this thesis is mainly used to highlight the impact cooperation and integration in the product chain might have on resource efficiency of biofuels. In this thesis connectedness is mainly dealt with from a qualitative perspective, e.g. by monitoring dynamism and trends. The concept of connectedness is further explained in section 3.2.

Business strategy is the strategic decisions made in order to be able to manage a company to achieve long-term objectives. In this thesis only business strategies potentially impacting the cooperation structure and connectedness are considered. 


\section{Biofuels and renewable energy in Sweden}

This chapter aims to provide some contextual understanding of biofuels in Sweden which could be helpful for readers not familiar with Swedish context.

The European Renewable Energy Directive sets targets for the share of renewables in the gross final energy consumption for all EU member states. Sweden has the most ambitious objective of all $27 \mathrm{EU}$ member states since the share of renewables was already relatively large as a starting position, $49 \%$ for 2020 (EU RES, 2009). This target has already been passed (Regeringskansliet, 2013) and Sweden could thus be regarded as a leading country regarding renewable energy at large, at least in Europe.

Regarding the biofuel share of the renewables, Sweden also has a leading position where almost $32 \%$ of the final domestic energy use came from biofuels in 2011, exceeding the share of oil which totalled 30\% (Swedish Bioenergy Association (Svebio), 2012), the majority of which was used in the transportation sector. The transportation sector represents one-fourth of domestic energy use in Sweden (Swedish Energy Agency, 2011), but about one-third of GHG emissions (Swedish Environmental Protection Agency, 2013). This makes it to the individually largest source of GHG emissions in Sweden and thereby an important sector to target in order to reduce total GHG emissions.

An important factor for the decrease of GHG emissions related to the gross final energy consumption in Sweden has been the successive transformation of the Swedish heating and cooling system including a large-scale introduction of renewables since 1980 (Westholm and Beland Lindahl, 2012) and the establishment of CHP plants connected to district heating grids which also have contributed to increased energy efficiency. It is also worth mentioning that electricity production in Sweden has specific characteristics due to early investments in hydropower and nuclear power, which contributes to the low price of electricity compared to many other European countries and also contributing to a low GHG emission profile of the Swedish electricity mix. The characteristics described above of the Swedish electricity production system are important in relation to biofuels since this probably has had an influence on the development of biofuel production systems in Sweden. The unique development of biogas production systems for vehicle fuel in Sweden (AEBIOM, 2009) is an interesting example of a development which may have been influenced by the characteristics of the Swedish electricity production system since the most common development, e.g. in Germany or Denmark, is to use biogas for electricity and heat production.

In the transportation sector the share of renewables has been approximately the same as in many other countries which is why Sweden has the same EU2020 objective (10\%) as all other EU member states. The development in Sweden has however been very rapid in recent years which accounts for the fact that the renewable share was already well above the target for 2020 by 2012 (Regeringskansliet, 2013). Taking a closer look at the energy used in the transportation sector, the energy consumption in 2012 was 92 TWh of which approximately $71 \%$ was used for road transport 
(Energimyndigheten, 2013). It is mainly in this sector where the renewable energy share has increased and in 2011 about $41 \%$ of the renewable share in this sector constituted of ethanol, $46 \%$ of biodiesel and $12 \%$ of biogas according to the Swedish Energy Agency (Swedish Energy Agency, 2012). However, about $50 \%$ of the ethanol and almost the entire biodiesel share consisted of low blending in petrol and diesel. Due to taxation rules for low blend biofuels and requirements from car manufacturers on fuel qualities there is an upper limit for how much of total biofuels can come from low-blend biofuels. This means that the main increase of biofuels has to come from the use of highblend and pure biofuels, e.g. ethanol (E85) and biogas. Regarding the infrastructural conditions for such increase it could be concluded that for ethanol there is a relatively well distributed infrastructure of filling stations due to a law obligating filling stations to provide renewable fuels (Swedish Paliament, 2009). For biogas the filling station network is good in many cities and towns in southern Sweden, but very sparse in the countryside and in the north of Sweden (Gasbilen, 2014).

Regarding the production conditions the production of biogas was almost entirely based on Swedish feedstock (93\%) in 2012 and also took place in Sweden (Swedish Energy Agency, 2013). Due to an increase in co-digestion plants where almost $90 \%$ of the gas produced is upgraded to fuel quality, $50 \%$ of the biogas produced in Sweden is currently utilized as vehicle fuel (Lantz, 2013). Co-digestion plants often use organic waste as feedstock and are therefore often co-located with actors handling large streams of organic waste such as waste handling companies in cities or food and feed industry. Regarding the feedstock for ethanol, around 31\% was produced from Swedish feedstock corresponding to $120,000 \mathrm{~m}^{3}$ according to the Swedish Energy Agency. Both ethanol and biodiesel in Sweden are mostly produced from biomass grown for the production of biofuels as one of the main purposes. However, since 2011 hydrotreated vegetable oil (HVO) produced from a by-product from the forest industry has increased for low-blend in fossil diesel. This low blend biodiesel produced from by-products has doubled the share of FAME, ethanol, HVO and DME (the aggregation level used in the Swedish Energy Agency statistics) produced from waste or by-products in 2012 (Swedish Energy Agency, 2013). Since the production of feedstock is responsible for a large share of the GHG emissions as well as other environmental impacts it makes a significant difference for the environmental performance of a biofuel if it is produced from waste/by-product or from primary feedstock such as wheat. This also relates to indirect land use changes (ILUC) which has been a much-debated issue, e.g. how to account for ILUC regarding primary feedstock used for biofuels (cf. Höglund et al., 2013). For waste or by-product feedstock land use is most often not an issue, but still there could be other issues regarding the use of such feedstock, e.g. how different byproducts and waste should be used in the most resource-efficient way. The choice of feedstock for biofuel production could also be an important issue from a policy perspective since certain types of waste/by-products are more beneficial to use from a GHG emission perspective, e.g. biogas production from manure (Lantz and Björnsson, 2011). From a societal perspective it is important to use all waste/by-products in a resource-efficient way regardless of whether it is used for biofuel production or something else. However from a biofuel perspective, the energy potential in the current waste streams is not enough to cover the needs of resource-efficient biofuels. 
There has been a tax exemption on biofuels for transport in Sweden for many years, but since 2012 it is restricted to biofuels fulfilling the sustainability criteria in the European Renewable Energy Directive (EU RES, 2009). For low blending of ethanol in petrol and biodiesel in diesel tax exemption has been allowed on volumes up to $5 \%$ (Regeringskansliet, 1994) which has been an important driver to increase the use of biofuels in Sweden. These subsidies have made biofuels and fossil fuels with low blending competitive with petrol and diesel, which has been important to increase the share of renewables (Riksrevisionen, 2011). However a new law regarding quota obligations for biofuels for transport (Sveriges Riksdag, 2013) was adopted by the Swedish government on the $20^{\text {th }}$ of November 2013, but by the time of the printing of this thesis it was not yet known when this new law will come into effect or how the current governmental means of control may change. 


\section{Related research}

This chapter describes some concepts and ideas from a selection of relevant research fields which I have considered relevant in relation to my research focus.

My research focus requires an inter-disciplinary approach, which is why several research fields could be of interest. However, in this thesis the research fields illustrated in Figure 2 have been considered most interesting. Figure 2 also illustrates how these research fields partly overlap from my research perspective.

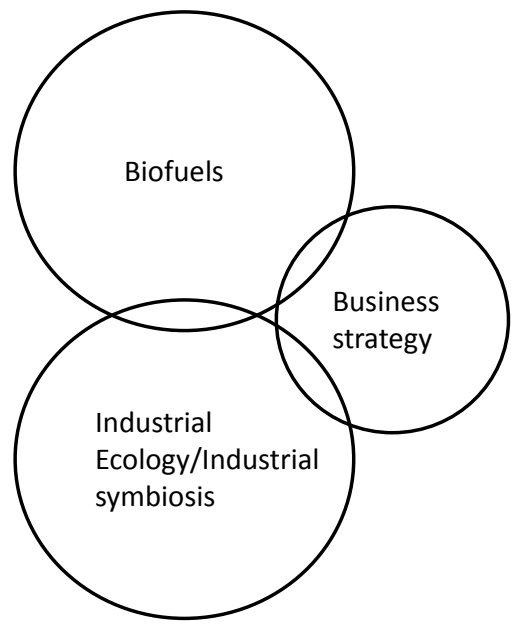

Figure 2. Illustration of the research fields considered relevant for my research focus in this thesis.

In the following sections each selected research field will be dealt with in order to clarify its relevance in this context as well as giving the background and motivation for some of the central concepts of interest in this thesis. An important purpose is also to further elaborate on the concept of resource efficiency in relation to biofuels, adding to the description of central concepts in section 1.2 .

Since the focus in this thesis is resource-efficient biofuels the research field of biofuels is of course relevant. Within the research field of biofuels empirical findings related to bioenergy and biofuels as well as methods on how to assess potentials and environmental performance of biofuels and bioenergy are found which is of interest in relation to this thesis. Since the focus is particularly on resource-efficient biofuels, research fields dealing with resource efficiency and environmental sustainability are also of interest. 


\subsection{Biofuels}

The research area referred to as biofuels has grown rapidly in the last decade which can be seen for example in the increasing number of scientific articles focusing on biofuels in many scientific journals. For this thesis I have focused on literature dealing with potentials related to biomass feedstock, environmental performance of biofuel production systems and resource efficiency in biofuels, especially biofuels for transportation. Biofuels are expected to contribute to the future society in several ways, e.g. mitigation of climate change, energy security and in the transition to a more sound and sustainable economy. However, in order to achieve these multiple goals not only must sufficient quantities of biofuels be produced, but they also need to be produced and used in a resource-efficient way (Ponton, 2009).

Biomass is a limited resource and a resource subject to many competing interests (cf. Haberl et al., 2007) for which reason much of the literature focuses on bioenergy potential and biomass feedstock potential for biofuels. Berndes et al. (2003) distinguish typically two types of studies of bioenergy potential common in literature; the resource-focused and the demand-driven. In resource focused studies the focus is on the availability of feedstock and typically assessments are made within extensive geographical areas such as continents and with a long time perspective (Offermann et al., 2011) giving low-resolution pictures of biomass potentials developed with a high level of abstraction. The validity of such assessments and their ability to give a realistic picture of what can be achieved regarding biofuels could be questioned following the reasoning by for instance Bagliani et al. (2010) and Kautto and Peck (2012), instead recognizing the importance of regional groundlevel work where the local scale is considered in order to be able to concretize ambitions and adjust directions of work at higher administrative levels. Biofuel potentials covering smaller areas, such as counties and further more with a focus on the actors' perspective, may contribute to assessments of greater value from an implementation perspective (Domac et al., 2011). These studies enable an understanding of integrated solutions where local resources, such as feedstock, energy systems, industrial facilities and actors, and specific local needs are considered to frame potentially resourceefficient systems interesting to implement from a societal perspective (cf. Mangoyana and Smith, 2011, Lam et al., 2011). However, the areal distribution differentiates the availability of primary biomass resources compared to for instance fossil resources which often have a punctiform distribution (cf. Wrigley, 1962). This implies that biomass resources are in the possession of many different actors all having their own rationales regarding the use of these resources which complicates the supply chain and produces insecurity regarding availability and supply. To some extent actors may respond to demand in the market or policy structures pushing for biofuels, but not all actors may act rationally (cf. Mignon, 2014) and barriers as well as drivers may vary between actors.

In demand-driven assessment studies, focus is on the drivers for biomass production and use and resources are assumed to be made available by a demand resulting from the economic 
competitiveness of biofuels or due to policy targets governing the development of biofuels (Lucia, 2012). The competitiveness of biofuels is however difficult to estimate since it is still a field of rapid development where major advancements in technology and economic rationalization is expected enabling the production of more competitive biofuels (de Wit et al., 2010). Also the more long term the assumptions, the more uncertainty is involved especially regarding constraints related to economy and socio-technical aspects related to implementation since these variables are often regarded as less stable and more unpredictable compared for instance to technological constraints (Offermann et al., 2011). Hence biofuel potential stretching far ahead assuming large advancements in technology should be viewed with some scepticism and it is important to reflect upon the assumptions and choices made in order to be able to evaluate their relevance and usefulness.

In literature there are several different types of biofuel potential with different scoping, but due to some inconsistency in the terminology these are sometimes difficult to separate and compare (cf. Smeets et al., 2007, Hoogwijk, 2004, Verbruggen et al., 2010). However, there seem to be a few "perspectives" which can be relevant to have in mind considering different potentials, e.g. geographical, time, biomass types, share of biomass, energy, socio-technical and economic. These "perspectives" are further elaborated on in Paper 1, but in relation to this thesis it could be relevant to mention that in most studies of potential the geographical scoping focuses on land areas while aquatic environments such as the sea and inland lakes are not included.

In the biofuel literature there is also a focus on the land use issue and the competition between different needs for biomass in society. However, there are partly contradictory messages in the scientific community of biofuels (cf. Richard, 2012) where on one hand biofuels in some contexts are always considered in conflict with basic needs such as food and feed, while others think that there is a substantial potential to produce biofuels which society must not ignore in order to meet the foreseen multiple challenges it faces (Tilman et al., 2009). However the necessity to strive for resource-efficient use of biomass where environmental impact is kept at a reasonable level and where the use of valuable primary feedstock is minimized is something where there are almost no contrary opinions.

From this it follows that not only how much biofuel can be produced is in focus in the biofuels literature, but also how environmentally beneficial different biofuels are. Since the political ambitions and policy targets for biofuels most often are motivated by environmental and especially climate benefits the environmental performance of biofuels has been studied a lot. Hence an increased body of literature focuses on environmental assessment studies for different types of biofuel production systems (e.g.Börjesson and Berglund, 2006, Börjesson and Mattiasson, 2008, Börjesson, 2009, Börjesson and Tufvesson, 2011). Biofuels are evaluated on a life cycle basis for different feedstock, different types of conversion methods, and by using different allocation methods which potentially influence the environmental performance substantially (Cherubini, 2010b, Cherubini et al., 2009). Another issue that relates to biofuels and the potential competition with other needs is indirect land use change (ILUC) effects which can influence GHG emissions 
substantially (cf. Börjesson, 2009). How such effects from biofuel production should be estimated and accounted for is however an issue of debate in the scientific community as well as in many legislative bodies dealing with biofuel policies (European Academies Science Advisory Council., 2012, Malins, 2013). Using land use-efficient biofuels is however important in order to minimize such potential effects and one way is to use secondary raw materials as feedstock or to use all byproducts if primary feedstock is used.

Much of the biofuel literature is focused only on environmental performance, especially climate performance and energy efficiency, but in some cases the broader perspective of resourceefficiency is also considered (e.g. Börjesson and Mattiasson, 2008). Approaching biofuels from a resource efficiency perspective however requires an even broader, multidimensional approach. Industrial ecology is a research field aiming at a holistic approach for sustainability by setting up a comprehensive framework applicable to study interactions between modern technological society and the environment (Sokka, 2011) including aspects such as environment, economy, society and technology (Martin, 2013).

\subsection{Industrial Ecology and Industrial Symbiosis}

Industrial Ecology (IE) is a broad interdisciplinary field combining several different types of study objects, methods, and research fields, e.g. ecology, engineering, economics, business management, and institutional theory among others. One of the leading ideas within IE for moving towards sustainability is mimicking nature, i.e. striving for more closed loops (Isenmann, 2003, Baas, 2005).

"Industrial symbiosis (IS) is a central concept of industrial ecology" (Sokka, 2011), dealing for instance with the transformation of linear industrial production systems into closed-loop systems (Lowe and Evans, 1995). The focus is on how resource efficiency and economic efficiency can improve by closing loops through physical exchanges of materials, energy, water, and by-products outside traditional supply chain paths, i.e., cooperation between traditionally separate industries (Chertow, 2000). Such "over the fence" or inter-firm forms of cooperation are often referred to as synergies in IS literature, hinting at their hypothetical mutually beneficial nature (Chertow and Lombardi, 2005). Sometimes there is a distinction made between by-product synergies and utility synergies (e.g. energy and water) since the prerequisites for these exchanges differ, where utility synergies require proximity due to the need of set infrastructure (van Beers et al., 2007) while byproduct exchanges often do not have those requirements.

In IS literature cooperation on an inter-firm level is strongly associated with improved competitiveness, often through improved natural resource efficiency, but the opportunities of IS should however according to Lombardi \& Laybourn (2012) be regarded as much broader. Besides information sharing which has been included in the IS concept by for instance Erkman (1997) much earlier their definition suggests that the essence of IS should be communicated as a tool for 
innovative green growth. Hence, it could be regarded as a way to reach eco-efficiency by added value.

In relation to the biofuel industry this tool seems to fit very well since there is a need for resource efficiency and economic efficiency as well as eco-innovation. Most research within the industrial symbiosis field focuses on industry in general and not on the biofuel industry in particular. However, according to Martin et al. (2014) focusing on IS within the biofuel industry there are many possibilities to improve environmental performance through exchanges of material and energy. Furthermore, Börjesson (2009) states that two of the most important components of an ethanol production system from a greenhouse gas (GHG) perspective is how by-products are used and what energy system is used, i.e., how the material and energy flows are organized in IS terms.

In IS literature the concept of connectedness is sometimes used, referring to the level of cooperation in terms of material and energy exchanges between different actors in an industrial system. The concept of connectedness is borrowed from theoretical ecology (Hardy and Graedel, 2002) where it is a strictly quantitative measurement used together with diversity to study the stability, productivity and functioning of natural communities, generally defined as the ratio between the numbers of actual interactions to the number of possible interactions in a community (Wright et al., 2009). Transferred to an industrial case this implies for instance that a company with several types of feedstock, products or costumer groups has a greater connectedness and will be more resilient to changed conditions than a company mainly relying on one feedstock, one main product which is sold to one type of customer. The diversity in an industrial network is also of relevance considering for instance to what extent different types of organizations are involved (Ruth and Davidsdottir, 2009). Within IS literature there is often also an implicit understanding that increased connectedness leads to reduced environmental impact, but there are only a few quantitative studies regarding this in literature (Boons et al., 2011). Theoretically this assumption could however be derived from the assumption that increased connectedness often leads to locally available by-products or secondary energy (such as heat) replacing previous supplies assumed to involve larger negative impact. It is important however also to focus on the characteristics of the individual connections and not only on the number, since the reduced negative impact will differ due to e.g. the type and the size of cooperation (Hardy and Graedel, 2002). From this reasoning it seems reasonable to assume that the level of connectedness is of relevance for the resource efficiency of industrial systems, which is why it is of interest in this thesis.

Biofuel production processes involves many material and energy inputs and outputs (Martin, 2010) where improved resource efficiency and economic performance potentially could be gained by employing IS ideas. Even though opportunities exist from a material or energy perspective to increase local industrial connectedness, in order to utilize synergistic opportunities, there is also a need for actors with the ability to take advantage of them and overcome the organizational, sociological and economic challenges related to their realization. This refers to the importance of having the actors' perspective emphasized often in the IS literature. The challenges of realizing IS by 
inter-organizational and/or cross-sector interaction and cooperation has been addressed by many scholars in the IS literature (e.g. Jacobsen, 2009, Wolf, 2007, Baas, 2005, Côté and Cohen-Rosenthal, 1998). Wolf (2004) also seeks guidance in more economically and organizationally oriented research fields such as cluster theory and inter-organizational relationships and finds some interesting literature although mainly related to management issues. According to Karlsson \& Wolf (2008) IS could also lead to economic benefits and competitiveness in the long or short term, which is why it is also interesting from a management perspective. In the case of biofuels, policy is also sometimes involved, which could make IS potentially more interesting e.g. from a business strategy perspective (cf. Esty and Porter, 1998).

\subsection{Business strategy}

Business strategy is a very broad field, and is focused on here only from the perspective of synergistic cooperation and business opportunities and competitiveness related to improved resource efficiency.

Economic competiveness is of course a necessary pre-condition for companies to be sustainable over a longer period of time. The economy of scale strategy has been commonly used in biofuel production (cf. van den Wall Bake et al., 2009, Hettinga et al., 2009) as well as in business in general (Panzar and Willig, 1977). It could however be argued that large-scale centralized biofuel production often leads to reduced resource efficiency and unsustainable practices since it distances production from the market and hides environmental impact along the supply chain (Mirata et al., 2005). Biofuel production systems with a limited geographical scope, e.g. a region, could contribute to reducing transportation distances during production and thereby increase resource efficiency. A limited geographical scope also alleviates cyclic flows which are a prerequisite when aiming for sustainable production systems. According to Mangoyana \& Smith (2011) the integration of smallscale decentralized bioenergy systems has benefits related to the integration possibilities with other production systems, which increases opportunities for closed loop models, allowing waste materials from one process to be used as inputs in other production processes as well as for synergies related to the feedstock production which is an important step in the bioenergy production chain.

Another business strategy to reach competiveness is the economy of scope strategy, which is applicable when it is cheaper to manufacture two or more products in parallel in multi-product firms (Panzar, 1981) than to produce the products separately. Considering biofuels from a business strategy perspective there are many ways to increase the value of the manufactured products by the economy of scope strategy. The biomass has an intrinsic value which can be exploited by refining different valuable compounds. Using the intrinsic value of biomass only for low-value products such as fuel, electricity and heat could be regarded as a waste of resources (De Wilt, 2008). Through the development of biofuel production systems based on the principles of diversification (i.e., economy of scope) and valorisation the possibility to create economically viable biofuel 
production systems could be increased. In literature biomass-based production systems based on this concept are often referred to as biorefineries, for which the resource efficiency potential and environmental benefits are often emphasized as an important feature besides the economic potential (Fatih Demirbas, 2009, Wellisch et al., 2010, Cherubini, 2010a).

If both economic competitiveness and environmental performance are important as in the case of biofuels, business strategies and business models must consider both these perspectives. Actors create business strategies reflecting the context they are in, also including prospected future development. They change over time due to changed external conditions as well as internal changes of conditions within the companies, e.g. size and interval of investments creating windows of opportunity and lock-in situations (cf. Karlsson and Wolf, 2008, Boons and Lüdeke-Freund, 2013). This implies that the economic incentives for cooperation projects improving resource efficiency and environmental performance vary over time within the same company, especially when cooperation involves large investments. In cases where less investments is required, business strategies could be more short term and reactive for instance to policy incentives or to short-term market opportunities. Business strategies could also reflect more long-term ambitions such as green branding where no direct economic incentives exist, but investments are made to secure future competiveness. 


\section{$4 \quad$ Methodology}

This chapter describes how the studies have been conducted in order to answer the research questions in this thesis. Initially the overall research design is presented and motivated together with the story of my research journey towards this thesis. The parts that follow present the data collection methods employed and analytical methods together with a motivation of the choices made. At last some reflections about the strengths and limitations of the methods used are discussed.

Describing the overall research design and research journey together as in this thesis is not common practice, but here motivated by the explorative and inductive approach of the studies where the outline and the journey are inseparably intertwined.

\subsection{Overall research design and research journey}

This research project was approached in an explorative way. Explorative research is suitable for new research fields or topics where knowledge is scant (Yin, 1994). Biofuels are not a new research field or topic, but studies approaching conditions for biofuel production also from the actors' perspective are less common. The two main research questions (RQ1 and RQ2) aim at highlighting the conditions for resource-efficient production of biofuels for transport from two different perspectives: the regional resource perspective and the biofuel producers' perspective. By combining these two perspectives the ambition was to get a more multifaceted picture of the conditions for resource-efficient production of biofuels for transport by also including the practitioners' perspective. It could be argued that other perspectives could also be of relevance (e.g. the users' perspective etc.), but in this thesis mainly these two perspectives were explored by using the research questions presented in chapter 1.1.

RQ1 has an explorative nature, thus the research process developed gradually and one step lead to the next forming the series of data collection and analysis steps illustrated in Figure 3 ending with a validation step. The data collection methods used are a combination of qualitative and quantitative methods which could be a beneficial approach according for instance to Holme \& Solvang (1996) since the data collected might mutually strengthen each other. The choices of methods and analytical approaches will be further commented on in the following three sections in this thesis: data collection methods, analysis, and reflections on methodological strengths and limitations. 


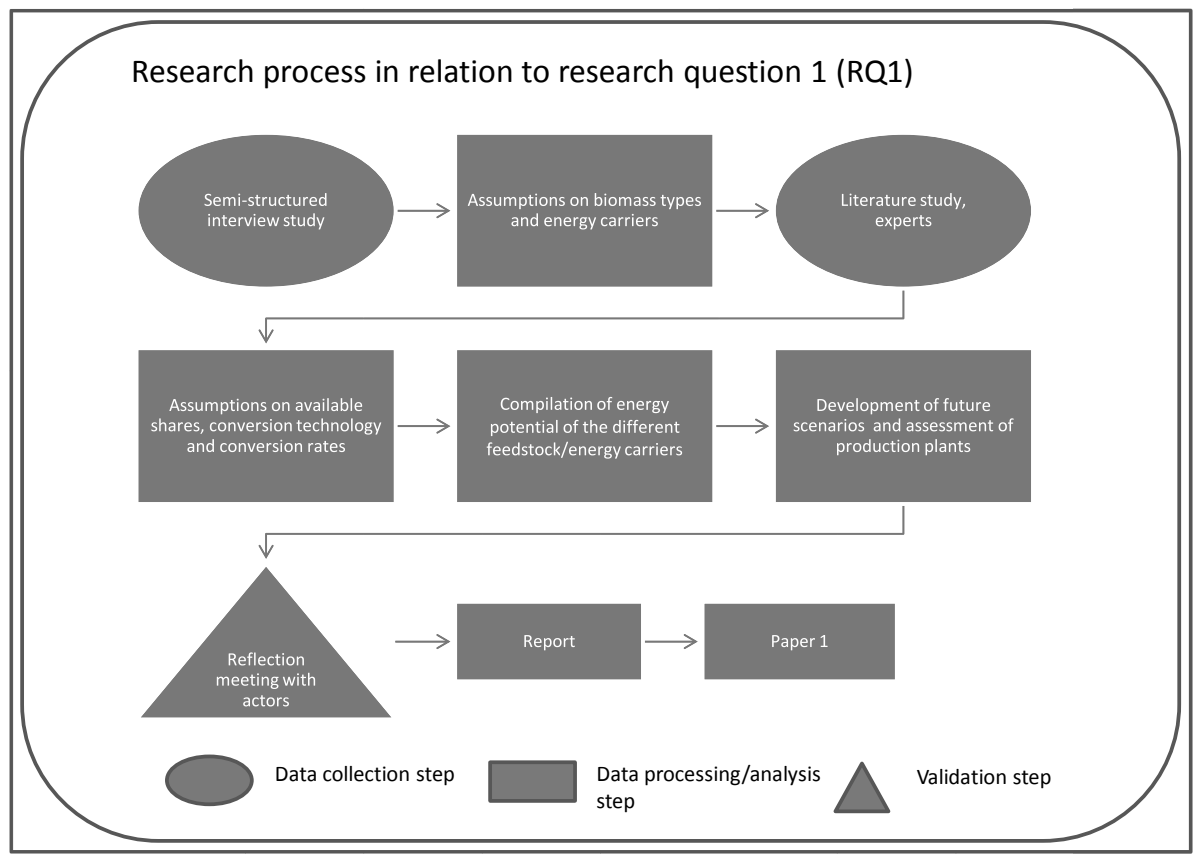

Figure 3. Illustration of the research process in relation to RQ1.

All the steps in the process followed naturally on each other which is typical for explorative research where one step gives input to the next. Such an inductive approach is according to Wallén (1993) often applicable in explorative research and thus applicable here. For instance the semi-structured interviews, performed with biofuel actors as take-off in the study, was a way to build a platform of insights for making credible assumptions from which the sub-questions could be approached. In this case it was seen as a suitable way to move from an unprejudiced platform to an informed platform influenced by the actors' perspective which is a consistently preferential perspective throughout this thesis. With this approach it was also possible to approach the study object of Östergötland by choosing respondents related to this area and thereby capture some of the regional characteristics. Using only one region provided better possibilities to catch more of the complexity related to some of the aspects, e.g. socio-technical aspects, important in relation to the scenario building (see Figure 3). To approach the challenges of implementation of the assessed biofuel potential, the need of new biofuel production plants was also addressed in a sub-question to RQ1. 
According to Stake (1995) the ability to capture the complexity of a case is a typical benefit of single case studies. The study has similarities with case studies, but the ambition was also to arrive at a result of more general interest than what single case studies are normally considered to generate. One example is the first sub-question calling for a more generally applicable tool or methodology for regional biofuel assessment studies, which could be regarded as an inductively derived outcome from the study and the research process illustrated in Figure 3. Another example is that resource efficiency had to be conceptualized in order to approach RQ1, which also inductively generated a concept of more general interest. The research process could also be seen as an iterative process where new data or new analytical insights were used continuously to reconsider assumptions and estimates. The study was first presented in an extensive report and later also transformed into Paper 1 attached to this thesis.

Using the county of Östergötland as a region for the study was convenient since the initial study was partly funded by Tekniska Verken $A B$, which is a municipal utility company with operation mainly in Östergötland. It was also convenient since I work at Linköping University situated in Östergötland where my colleagues already were working on other related projects in the region which could potentially provide synergies.

RQ2 was aimed to further bring in the actors' perspective by also involving the perspective of some biofuel producers in relation to the aim of this thesis. Existing biofuel producers are here considered important informants regarding conditions for resource-efficient production of biofuels even if it cannot be taken for granted that they will be the ones producing biofuels in the future. Biofuel producers design and create the biofuel production systems to a large extent and they thereby largely impact the resource efficiency of the systems. The takeoff in RQ2 was a bit different compared to RQ1 since I got the first input of information to the study from a reference group meeting with some biofuel actors, with whom the research group I am part of has collaborated for many years. The reference group meetings have among other things the purpose of information sharing, and at this particular meeting information about planned changes potentially influencing the environmental and economic performance of existing biofuel production came up. This information was used as take off when approaching RQ2. RQ2 has an explorative nature in parity to RQ1, but the sub-questions also have more descriptive and explanatory features. Similarly to RQ1 the research process was built up by data collection and analysis steps following naturally on each other followed by a validation step in the end (see Figure 4). 


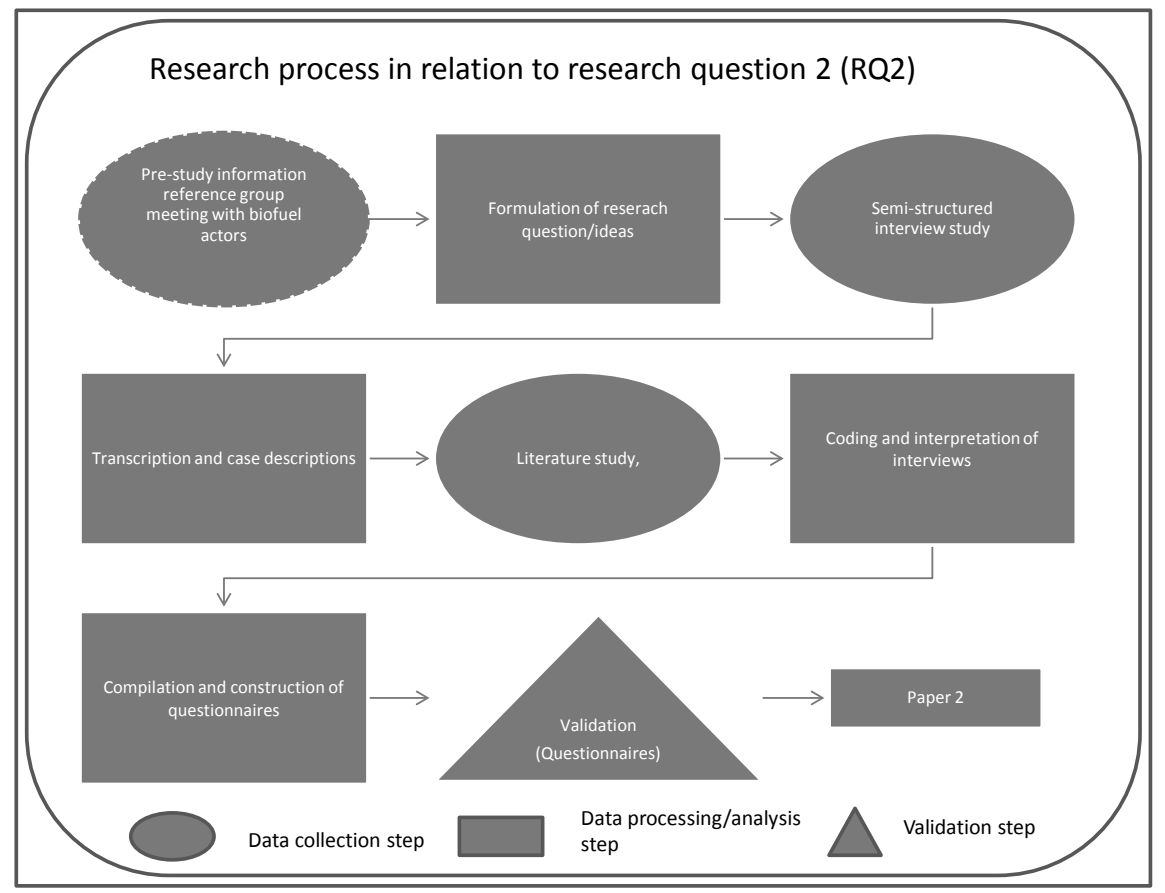

Figure 4. Illustration of the research process in relation to RQ2.

The pre-study information gained at the reference group meeting served as a good platform for takeoff in the research process in relation to RQ2, e.g. it contributed ideas for the construction of the interview guide used for the semi-structured interview study. In this case the reference group meeting could be seen as similar to a pilot study, which is why the first one or two interviews did not need to perform this function, which otherwise is recommended practice (Trost, 2010, Holme and Solvang, 1996, Bryman, 2002). The interview questions focused not only on the current situation, but also on dynamics with a strong focus on change and development (also including prospective development). Such a process-oriented approach is typical in qualitative research (Bryman, 2002) and suitable when the ambition is to describe and understand processes or a context (the system perspective) (Holme and Solvang, 1996). The ambition in relation to RQ2 was first and foremost to describe and explain the dynamics in the individual cases by investigating how some existing biofuel producers in Sweden think and act. However, the study could also be seen as a multiple case study since the respondents are considered to represent "biofuel producers" in Sweden. By exploring the mechanisms and rationales behind the dynamics in these companies possibly a better understanding of the actors' perspective of biofuel production could be built, also including for 
instance the business dimension of resource-efficient biofuel production which of course is an important factor for realization.

The two papers appended to this thesis were written in the order in which they appear. Paper 1 contributed to answer mainly RQ1. Paper 2 mainly contributed to answer RQ2.

\subsection{Data collection}

From Figure 3 and 4 it could be seen that in order to answer the research questions the research process contained several steps of data collection separated by analytical steps. The data collection steps are connected since the processing or analysis of one data set initiates a supplementary data collection step so that necessary data for answering the research questions are accumulated along the research process. Table 1 gives an overview of the data collection methods and validation methods used in relation to the two research questions and the two papers and are also supplemented with the sources used for data collection.

Table 1. Overview of data collection methods and sources used for Papers 1 and 2.

\begin{tabular}{|c|c|c|c|c|c|c|}
\hline $\begin{array}{l}\text { Research } \\
\text { question }\end{array}$ & $\begin{array}{l}\mathrm{Pa} \\
\text { per }\end{array}$ & $\begin{array}{c}\text { Pre-study } \\
\text { information }\end{array}$ & $\begin{array}{c}\text { Interview } \\
\text { study }\end{array}$ & Literature study & Experts & Validation \\
\hline RQ1 & 1 & & $\begin{array}{l}\text { semi- } \\
\text { structured } \\
\text { interview } \\
\text { study with } \\
\text { regional } \\
\text { biofuel } \\
\text { actors }\end{array}$ & $\begin{array}{l}\text { "grey literature" (such } \\
\text { as national reports from } \\
\text { authorities, NGOs, } \\
\text { companies, } \\
\text { international } \\
\text { organizations and } \\
\text { legislative documents), } \\
\text { scientific literature }\end{array}$ & $\begin{array}{l}\text { experts in } \\
\text { industry } \\
\text { and } \\
\text { academia }\end{array}$ & $\begin{array}{l}\text { reflection } \\
\text { meetings } \\
\text { with biofuel } \\
\text { actors }\end{array}$ \\
\hline RQ2 & 2 & $\begin{array}{l}\text { reference } \\
\text { group } \\
\text { meeting } \\
\text { with biofuel } \\
\text { actors }\end{array}$ & $\begin{array}{l}\text { Semi- } \\
\text { structured } \\
\text { interview } \\
\text { study with } \\
\text { biofuel } \\
\text { producers }\end{array}$ & $\begin{array}{l}\text { scientific literature, } \\
\text { websites (company } \\
\text { websites etc.) }\end{array}$ & & $\begin{array}{l}\text { respondent } \\
\text { validation } \\
\text { question- } \\
\text { naire }\end{array}$ \\
\hline
\end{tabular}


With regard to Table 1 it is necessary to emphasize that although the data collection methods used in relation to RQ1 and RQ2 seems to be similar, they were used to collect different kinds of data. The literature study in relation to RQ1 mainly focused on quantitative data such as numbers while the literature study in relation to RQ2 mainly focused on qualitative data, such as explanatory and descriptive data.

\subsubsection{Data collection RQ1}

How the data collection methods listed in Table 1 were used in relation to Research Question 1 is further described in the following section.

Interview study

The interviews performed in relation to RQ1 provided a good opportunity to learn about biofuels in general and in the Östergötland context in particular. The selection of respondents was made in order to include many different actors in society related to biofuels to get a broad picture of regional perspectives on biofuels. The interview guide consisted of only four open questions used mainly to thematically restrict the interview, while letting the respondent influence the direction of the interview. All the interviews were performed face-to-face. They were recorded and later also transcribed. They were however mainly used to form a knowledge base and a framework for making necessary assumptions and estimations for the quantitative part of the study and for setting the scenarios.

\section{Literature study and experts}

In order to be able to complete the quantitative assessments of the different feedstocks and the scenario development, complementary literature studies of "grey" and scientific literature and information from industrial and academic experts were used. Theoretical figures or numbers from laboratory studies were used in some cases when the feedstock included were unconventional and thus full-scale data were unavailable.

\section{Validation}

The result of this study was first presented in a report. Before developing it into Paper 1 , a reference group of biofuel actors were asked to reflect upon the assessed biofuel potential, for which purpose two meetings were arranged in order to gather feed-back from different biofuel actors. 


\subsubsection{Data collection RQ2}

How the data collection methods listed in Table 1 were used in relation to Research Question 2 is further described in the following section.

\section{Interview study}

The first data were acquired in the reference group meeting even before the actual research process was initiated in relation to RQ2. According to Stake (1995) however, there is no particular moment when the data collection of a study begins or when the analysis begins. This pre-study information contributed to the formation of the basic ideas behind the semi-structured interview study performed with biofuel producers. In the reference group meeting we had just been briefly informed about the ongoing changes which we now wanted to learn more about by performing an in-depth study. Two respondents were selected from the reference group meeting, while the selection of two additional respondents was based on an ambition to get all three biofuels included in Paper 1, represented in the study. An additional biofuel producer for biodiesel was selected as well as a private biogas company. There were only one biodiesel producer found fulfilling our criteria of full-scale production and extensive use of Swedish feedstock while for biogas production there are many more actors. A private biogas actor was added to complement the municipal actor already selected. The selected biofuel producers are all major actors in the Swedish biofuel industry, and hence regarded as relevant respondents in relation to RQ2 in this thesis.

Since the discussion about change of strategies so far seemed to be mainly on a strategic level we decided to interview primarily the CEOs of the companies. In total four biofuel producing companies were represented in the study and fortunately all four CEOs were willing to take part in the study.

The interview guide contained six questions of different character. The questions also contained a practical task, where the respondents were asked to make a sketch of energy and material flows in the production plant or plants on a sheet of paper. The interviews were performed face-to-face and recorded. Later full transcriptions were made.

\section{Literature study}

Scientific literature on resource efficiency and cooperation was used as inspiration when formulating the analytical questions. The literature study also helped to form ideas about concepts and to increase the understanding of how they have been used in other contexts.

Company websites, etc. were also searched for additional information relevant for the studied cases and for further understanding of the context.

\section{Validation}

All the respondents were offered a copy of their transcribed interview, but only one choose to have it. In order to validate the results respondent validation questionnaires were constructed and sent by e-mail to the four respondents. The validation questionnaires did not however cover the entire result of this study, but contained a list of important cooperation projects identified linked to the 
critical factors which the respondents had mentioned in relation to the different cooperation projects. The respondents were asked to confirm this information, but also to rate the strength of the environmental driver and economic driver in relation to each cooperation project on a threepoint scale (low, medium, high).

Supplementary telephone calls had to be made in order to get the validation questionnaires completed. However, these telephone validation sessions also led to the acquisition of valuable supplementary information in relation to the study.

\subsection{Analysis}

Thee analytical steps following the data collection steps were made using different analytical methodologies and approaches which are described below.

\subsubsection{Analytical approach RQ1}

The analysis in relation to Research Question 1 had a quantitative approach, containing a quantitative assessment in which scenario methodology was used.

\section{Quantitative assessment}

Quantitative data for different feedstocks were collected and gathered in an Excel spreadsheet. All background data compiled about available biomass, energy content, conversion rates, etc. were stored and sorted in this Excel spreadsheet, readily accessible for analysis.

\section{Scenario methodology}

Scenario methodology was used when summing up the different feedstocks included in the study. Scenario methodology is a way to handle uncertainties related to the future (Börjeson, 2006). In this case only two scenarios were created, hence no extensive scenario modelling has been made. It was a way however to handle assumptions regarding e.g. available feedstock and socio-technical development. It was considered important to clearly state the most important assumptions for the scenarios, but since a large number of assumptions and choices were involved it was not possible to transparently state all of them.

The analysis of the GHG reduction potential of the two scenarios was added to the two scenarios. Simplified calculations based on GHG reduction potentials for typical production pathways found in the EU RES Annex V (EU RES, 2009) were used. Hence, no full life cycle assessment (LCA) has been done in this study. 


\subsubsection{Analytical approach RQ2}

The analysis in relation to RQ2 had a qualitative approach based on systematic coding of the interviews, categorization and interpretation.

\section{Case descriptions and coding}

The full transcription of each interview was ordered chronologically from how the discussions developed during the interviews. In order to extract and structure the information from the interviews three analytical questions were constructed which were used to systematically analyze or code the transcriptions (cf. Holme and Solvang, 1996). Case descriptions were constructed based on the extracted information for each case company with some support also from the input/output schemes constructed by the respondents as part of the interview.

\section{Categorization and interpretation}

During the analysis important cooperation projects in each company were also listed together with critical factors mentioned by the respondent in relation to those cooperation projects. These lists of cooperation projects were later used as part of the validation questionnaire sent out to the respondents (see 4.2.2 above for more information).

The validation questionnaires when validated were used for backing up the analysis.

\subsection{Reflections on methodological strengths and limitations}

Both the quantitative and qualitative approach have their strengths and limitations, thus it is important to choose the right approach in relation to how the question is formulated (Holme and Solvang, 1996). The approach of combining qualitative and quantitative methods, as in the RQ1 approach, is often regarded as strengthening a study (Holme and Solvang, 1996) which was the ambition here. However, there could still be a problem with this approach since the answer to RQ1 is a number, which may give a false impression of accuracy and correctness (cf. Bryman, 2002). However, the result must always be viewed in conjunction with the methodological approach. Quantitatively oriented researchers in turn might criticize the qualitative approach instead since it leaves too much room for biased interpretation. Natural science is mostly positivistic implying a belief that knowledge is something that has been empirically tested or measured and not assessed or estimated (Wallén, 1993). However, it lies within the nature of predictions for the future, such as studies of potential, that they are not testable and not measurable which means that some kind of assessment or estimation is necessary. This type of study could still however be regarded as important since it could give valuable information on important choices of paths regarding future development. 


\section{Data collection and analysis of semi-structured interviews}

The interviews in relation to RQ1 were accomplished by me alone and due to my inexperience in the subject the initial interviews came to be very unrestricted which resulted in a heterogeneous empirical material which made analysis difficult. The respondents gave me a somewhat problematized view and an awareness of the challenges rather than the possibilities in biofuel development, which of course influenced the assumptions. However, the actors' perspective of biofuels was a goal for in this study and the result should be understood from this perspective.

The same problem of interpretation and analysis of the semi-structured interviews was experienced in relation to RQ2. However, at this point in time I had gained more experience and was more skilled in keeping the focus of the interviews. Additionally, two of the interviews were performed in cooperation with one of my supervisors.

\section{Selection of respondents}

A problem with choosing semi-structured interviews as methodology is that it restricts the number of respondents due to the fact that the processing and analysis of the data is very time consuming. Therefore it is very important that the selection of respondents is representative in relation to the scope of the study.

For the selection of respondents in relation to RQ1 we used our own network which of course might have influenced the validity of the study. However, biofuel actors are not a well-defined group, making it difficult to pick them out if we did not have this network. A few additional respondents were also suggested by the respondents during the interviews. Those together with our own network provided us with a good overview of actors who could provide us with information from which we could make a relevant selection in relation to the aim of the study.

The selection of respondents in relation to RQ2 was easier because two cases were already selected due to our ambition to do an in-depth study in the two cases where we had been informed about ongoing changes beforehand. Further on, the group of biofuel producers was better defined than biofuel actors in the first study, and the criteria set up in order to be of interest in the study reduced the number of possible choices substantially. This automatically gave us a representative selection to some extent.

\section{Validity}

Our choice to use only Östergötland in RQ1 could be seen as limiting the generalizability of the study. However, many heuristic insights were gained during the research process which can be used and applied to other contexts (cf. Merriam, 1994). The insights were collected and developed into a general methodology, presented in Paper 1, for regional biofuel assessments. However, the potential for biofuel substitution in Östergötland is of course not possible to flatly generalize to other regions in the world or even in Sweden. However, looking into the composition of the potential, useful ideas of which feedstocks could be interesting and which could be assumed to be 
of greater or lesser importance in terms of biofuel potentials might also be of interest for other regions.

Regarding RQ2, the external validity and the possibilities of generalization depends on how the study is regarded. It was assumed in the study that existing biofuel actors could give valuable information about conditions for resource-efficient biofuel production. However, the conditions are of course related to the current situation and how the current actors understand them, and it cannot be taken for granted that current producers will be the biofuel producers in the future. In this case, it might also be of interest to do two by two comparisons since the differences in the selected companies influence the generalizability. Comparisons between the two biogas companies and the ethanol and biodiesel case respectively were assumed to be of interest since these companies are more similar. This would limit the group in focus for generalization, but would probably increase the possibilities for generalizations.

\section{Reliability}

In quantitative research reproducibility is seen as important for the external reliability of a study, but in qualitative research this type of reproducibility is often seen as irrelevant since social processes or contexts cannot be "frozen" but will proceed (Bryman, 2002).

Instead credibility has been important to secure in both studies and for this respondent validation has been used. According to Bryman (2002) respondent validation is a methodology which is often used in qualitative research because it is a good way to confirm that the researcher has gained a credible picture of reality.

In relation to RQ 1 the two reflection meetings were assumed to secure credibility. Regarding the validation questionnaire sent out in relation to RQ2 a low response rate motivated follow-up telephone calls which however resulted in a final $75 \%$ response rate which was assumed to secure the credibility of the validated parts of the study. 


\section{Potential for biofuels for transport in Östergötland year 2030 and the challenges of implementation}

This chapter summarizes the results in paper 1 which are discussed in relation to the research questions and aim.

\subsection{Feedstock potential}

For the assessment of regional biofuel potential, four different feedstock categories were included: the waste, agriculture and forestry sectors, and aquatic environments inspired by a categorization by Cherubini (2010a). Within these sectors different feedstock categories were chosen (see Table 2) assumed to be relevant in the region in light of the biofuel assessment study for the year 2030 .

Feedstock from the waste and agricultural sectors is already used for biofuel production today while the forestry sector or aquatic environments could be regarded as unconventional sectors. However, there are also feedstock types within the waste and agricultural sectors which could be regarded unconventional regarding biofuel for transport applications, e.g. straw. By including unconventional feedstock, uncertainties increase in relation to conversion technologies as well as collection and pretreatment technology (e.g. the algae feedstock (Hansson et al., 2012, Mussgnug et al., 2010)).

The share of available land for production of biofuel feedstock is crucial regarding the potential and will also influence which crops are dedicated to biofuel feedstock production. Other needs such as food and feed have to be met prior to biofuel production and already approximately $15 \%$ of the available arable land in Östergötland is estimated to be used to grow grains for ethanol production, which in this study is assumed to continue through 2030.

Waste or by-product feedstock such as food waste, stillage, tall oil and process water from pulp and paper mills are dependent on population size and local consumption habits, or the industries producing the by-products. In this study the regional population is assumed to increase by $6.5 \%$ by 2030 (Karlsson, 2010). The industries are assumed to continue with their current production implying the production of the same amounts of waste or by-products. 
Table 2. Feedstock categories included in the study (Paper 1).

\begin{tabular}{|l|l|l|c|}
\hline Waste management & $\begin{array}{c}\text { Agricultural } \\
\text { sector }\end{array}$ & $\begin{array}{c}\text { Forestry sector, forest } \\
\text { industry }\end{array}$ & $\begin{array}{c}\text { Aquatic } \\
\text { environments }\end{array}$ \\
\hline Sludge from sewage treatment & Manure & $\begin{array}{l}\text { Process water from pulp } \\
\text { and paper industry }\end{array}$ & Reed \\
\hline Food industry by-products & $\begin{array}{l}\text { Agricultural } \\
\text { waste }\end{array}$ & Tall oil & $\begin{array}{c}\text { Algae, from } \\
\text { ocean }\end{array}$ \\
\hline $\begin{array}{l}\text { Food waste (households, canteen } \\
\text { and restaurant) }\end{array}$ & Grains & & $\begin{array}{c}\text { Farmed } \\
\text { mussels }\end{array}$ \\
\hline Used Cooking Oils (UCO) & Stillage & & \\
\hline Park and garden waste & Ley & & \\
\hline Landfills & Straw & & \\
\hline Slaughterhouse waste & & & \\
\hline
\end{tabular}

\subsection{Biofuel potential in Östergötland}

To assess the biofuel potential in Östergötland for 2030 two scenarios were created, the EXPAN (Expansion) scenario and the INNTEC (Innovation and Technology development) scenario. In the EXPAN scenario an expansion mainly in line with the present direction of development was assumed, mostly implying more resource-efficient use of material flows within the agricultural and waste sectors, but also anticipating some technological progress. In the INNTEC scenario greater progress in technological innovation was assumed.

One important assumption was that in the EXPAN and INNTEC $22.5 \%$ and $30 \%$ of available arable land respectively could be used to grow ley for biogas production. Rough estimates of the consequences of increasing the use of arable land for biofuel production to this extent indicated that the risk of conflicting interests such as food production and grains for ethanol production was moderate. Using ley for biogas production as dedicated energy crop on this additional land was motivated by its land use efficiency, but also by the other benefits ley potentially can offer in terms of improved agricultural practices in areas dominated by annual crops (cf. Jokela, 2009). Another important assumption was not to include lignocellulose material such as wood from the forestry sector. This is an assumption which could be questioned since forest materials are an important feedstock in many studies of biofuel potential. However, this is a decision based on the regional actors' perspective as well as an estimation of the regional prerequisites for such a development. The forest industry in Scandinavia has been described as fairly passive (Näyhä and Pesonen, 2012) in relation to what would be required if the expectations of development towards biorefineries, where biofuels are supposed to be among the products, would be realized within the timeframe of the study. However, lignocellulosic material from agriculture such as straw was included in the study.

Based on the assumptions in the EXPAN and INNTEC scenarios the biofuel for transport potential in Östergötland in 2030 was estimated at $1300 \mathrm{GWh} /$ year and $2100 \mathrm{GWh}$ /year respectively (Figure 5). This potential also includes the current ethanol production and biogas production estimated at 
approximately $500 \mathrm{GWh} /$ year. The energy need for road transport in Östergötland in 2030 was assumed to be the same as today, $4000 \mathrm{GWh} /$ year (Ersson et al., 2012), implying that with a development in line with the EXPAN scenario up to $30 \%$ of the need could be covered while for INNTEC approximately $50 \%$ could be covered. In order to get a rough estimate of the climate impact of the EXPAN and INNTEC scenarios simplified GHG emission calculations were made based on typical biofuel pathways in Annex V part A and B in the EU RES (2009) when available or based on assumptions declared in the appended supplementary data sheet to Paper 1 . If assuming that the rest of the road transport in $\mathbf{2 0 3 0}$ would be covered with fossil fuels the GHG emission savings for the INNTEC scenario was estimated at $39 \%$ and for the EXPAN scenario at $23 \%$. Notably ILUC (Indirect Land Use Change) has not been considered in these calculations and it should also be added that the EU RES figures have been criticized for using too low figures for $\mathrm{N}_{2} \mathrm{O}$ emissions (Reijnders and Huijbregts, 2011, European Academies Science Advisory Council., 2012).

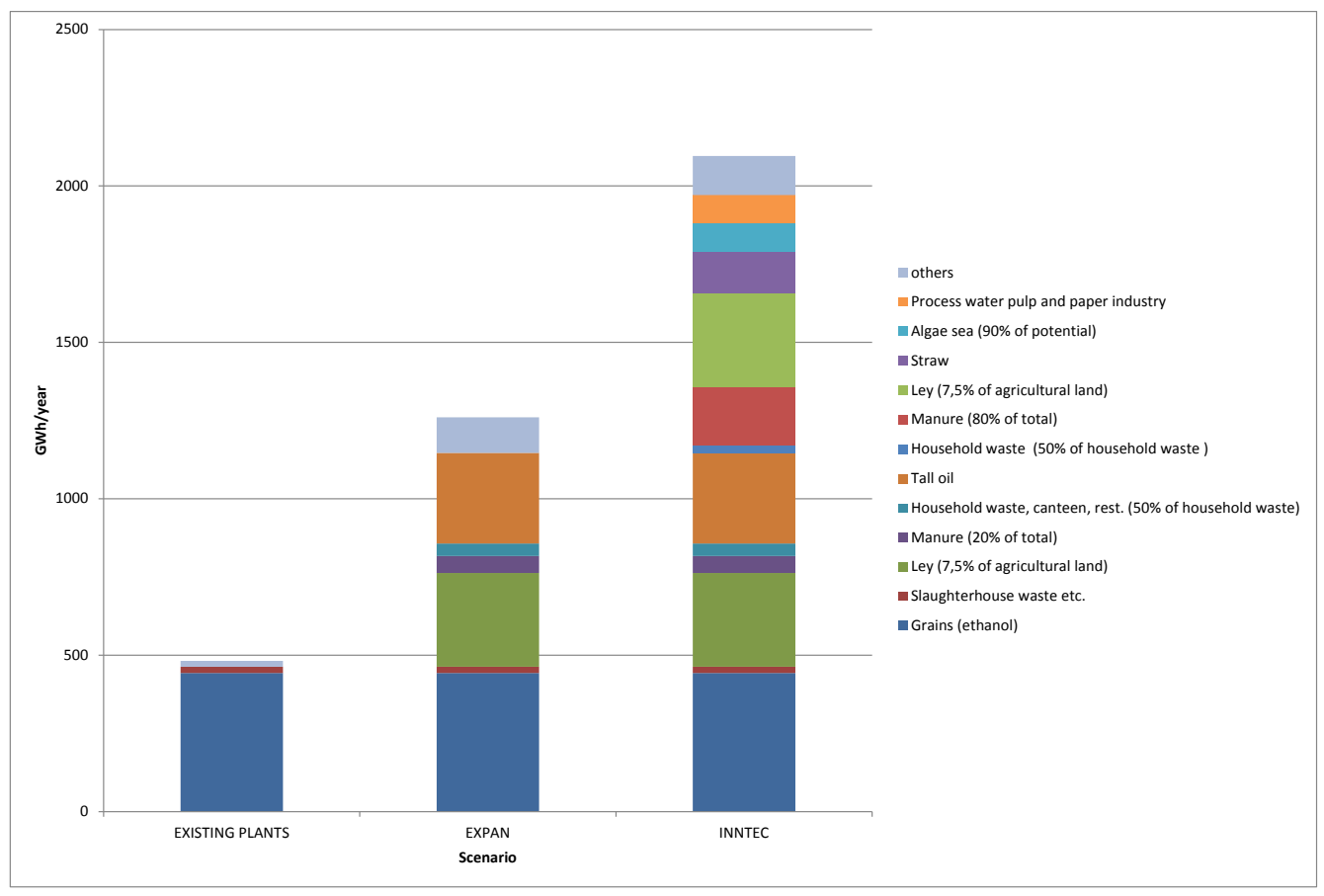

Figure 5. Energy potential for the EXPAN and INNTEC scenario (Paper 1). 
Some of the potentials are divided between the EXPAN and INNTEC scenario since it is assumed that the technology/cost required to utilize them differs (see Figure 5). For household waste for instance, it was assumed that a common self-sorting rate is $50 \%$, but with innovative collection technology it is assumed that the remaining $50 \%$ could also be used and therefore it is included in the INNTEC scenario. The category "Others" in Figure 5, include thin stillage, used cooking oil, agricultural waste, industrial food waste, sewage treatment (optimized digestion), landfill, algae sea (10\% of potential), reed from the coast and park and garden waste (dry digestion) in the EXPAN scenario. Regarding the INNTEC scenario the category "others" in Figure 5 additionally includes sewage treatment (50\% of total) and farmed mussels.

\subsection{Approaching the challenges of implementation}

The assessed biofuel potential presents a "theoretical" potential (cf. Offermann et al., 2011) and has to be put in perspective of the challenges related to implementation issues. The implementation issues were mainly approached in paper 1 from a regional resource perspective providing information on a theoretical and conceptual level. This included an assessment of the need for new biofuel production plants, considered an important barrier in relation to the realization of the biofuel potential. It also included the conceptualization of some important aspects related to resource efficient biofuel production. The concept of multifunctionality was also applied to emphasize the importance of having a multidimensional perspective in relation to resource efficiency in biofuel production systems. However, only a minor part of all relevant conditions for implementation is covered with this approach.

\subsubsection{Need of new production plants}

The largest part of the biofuel potential in the EXPAN scenario is biogas production (42\%). If tall oil and ethanol based on grain, for which plants already exists, is excluded there is only a need to build new plants for biogas production. To realize a biogas potential of $463 \mathrm{GWh} /$ year in the EXPAN scenario a conceptual idea sketch of 25 new biogas plants was created which can be seen in Table 3 . 
Table 3. Biofuel production plants needed to realize $463 \mathrm{GWh} /$ year of biogas (Paper 1).

\begin{tabular}{|l|l|r|r|}
\hline \multicolumn{1}{|c|}{ Feedstock } & \multicolumn{1}{|c|}{ Type of plant } & \multicolumn{1}{|c|}{$\begin{array}{c}\text { Energy } \\
\text { potential } \\
\text { (GWh) }\end{array}$} & Number of plants \\
\hline $\begin{array}{l}\text { Ley (7.5\%)/Tops, sorted out } \\
\text { potatoes etc./Stillage }\end{array}$ & Biogas & 331 & 6 \\
\hline Manure (20\%) & Biogas (farm plants) & 54 & 11 \\
\hline $\begin{array}{l}\text { Household waste, } \\
\text { canteen/restaurant, } \\
\begin{array}{l}\text { Industrial food waste } \\
\text { (potential) }\end{array}\end{array}$ & $\begin{array}{l}\text { Biogas co-digestion } \\
\text { (hygienization) }\end{array}$ & 54 & 2 \\
\hline Algae sea (10\%)/Reed coast & Biogas & 11 & 2 \\
\hline Park and garden waste & Biogas (dry digestion) & 13 & 4 \\
\hline Total & 463 \\
\hline
\end{tabular}

The type and size of the plants in the conceptual sketch was based on existing technology or technology expected to be implemented soon. A balance between economy of scale and proximity to feedstock and biofertilizer offset was also strived for in the sketch. Biogas feedstock generally requires short transportation distances but it differs with feedstock used and the biofertilizer produced (Berglund and Börjesson, 2006, Benjaminsson and Linné, 2007, Boons and Mendoza, 2010). The conceptual sketch should be regarded as more of a calculation exercise presenting one way out of many to realize the production of $463 \mathrm{GWh} /$ year of biogas estimated in the EXPAN scenario.

\subsubsection{Integrated, resource-efficient \& multi-functional biofuel production systems}

In order to produce biofuels that contribute to sustainability and reduced climate impact resourceefficient and integrated production systems well embedded in society are required. In contrast, centralized large-scale biofuel production plants requiring large amounts of fossil primary energy and based on feedstock from monoculture agricultural practices converted into one product are not considered to contribute to sustainability (cf. Figure 1 in section 1.2)(Feiz et al., 2013, cf. Mangoyana and Smith, 2011, Ponton, 2009). Integrated and well embedded biofuel production systems require coordination and cooperation of different actors at different levels in society which makes the management of the systems complicated and the development of such production systems challenging (Dautzenberg and Hanf, 2008). To get such biofuel production systems in place would in many cases contribute to increased energy security and reduced climate impact but also with other environmental benefits as well as positive societal synergies. Hence the perception of biofuel production systems must be widened to also include the multidimensional features of biofuel production systems (cf. the concept of resource efficiency described in section 1.2). The concept of multifunctionality (cf. Börjesson and Berndes, 2006, Ericsson et al., 2009) could be used to characterize biofuel production systems and help clarify the external effects, here exemplified by 
characterizing the assessed biofuel potential regarding such features (see Table 4). The assessed biofuel potential could be defined as multifunctional since all feedstock in the potential contributes at least one more function on a life cycle basis besides being an energy carrier and reducing the climate impact.

Table 4. Multifunctionality of the biofuel potential in Östergötland (Paper 1).

\begin{tabular}{|c|c|c|c|}
\hline Feedstock & $\begin{array}{l}\text { Main } \\
\text { product }\end{array}$ & Secondary product & Service or ecosystem service \\
\hline Grains & Ethanol & $\begin{array}{l}\text { Dried Distillers Grains with } \\
\text { Solubles (DDGS), biogas, bio- } \\
\text { fertilizer }\end{array}$ & Nutrient recycling \\
\hline Slaughterhouse waste & Biogas & Biofertilizer & $\begin{array}{l}\text { Biological waste treatment, nutrient } \\
\text { recycling }\end{array}$ \\
\hline $\begin{array}{l}\text { Sludge from sewage } \\
\text { treatment }\end{array}$ & Biogas & $\begin{array}{l}\text { Biofertilizer or construction } \\
\text { material }\end{array}$ & $\begin{array}{l}\text { Biological waste treatment, nutrient } \\
\text { recycling }\end{array}$ \\
\hline $\begin{array}{l}\text { Used cooking oils } \\
\text { (UCO) }\end{array}$ & Biodiesel & $\begin{array}{l}\text { Glycerol (for biogas production } \\
\text { or other use) }\end{array}$ & Biological waste treatment \\
\hline Ley & Biogas & Biofertilizer & $\begin{array}{l}\text { Improve the sustainability of } \\
\text { agricultural practices }\end{array}$ \\
\hline $\begin{array}{l}\text { Agricultural waste } \\
\text { excluding straw }\end{array}$ & Biogas & Biofertilizer & $\begin{array}{l}\text { Reduced GHG emissions from the } \\
\text { decomposition of agricultural by- } \\
\text { products }\end{array}$ \\
\hline Manure & Biogas & $\begin{array}{l}\text { Biofertilizer with reduced odour } \\
\text { and improved nutrient availability }\end{array}$ & $\begin{array}{l}\text { Reduced GHG emissions from storage } \\
\text { and spreading }\end{array}$ \\
\hline Industrial food waste & Biogas & Biofertilizer & $\begin{array}{l}\text { Biological waste treatment, nutrient } \\
\text { recycling }\end{array}$ \\
\hline Food waste & Biogas & Biofertilizer & $\begin{array}{l}\text { Biological waste treatment, nutrient } \\
\text { recycling }\end{array}$ \\
\hline Tall oil & Biodiesel & & $\begin{array}{l}\text { Upgraded use compared to the use as } \\
\text { heating oil }\end{array}$ \\
\hline Landfill gas & Biogas & & $\begin{array}{l}\text { Reduce methane emission to } \\
\text { atmosphere }\end{array}$ \\
\hline Algae, sea & Biogas & Biofertilizer & $\begin{array}{l}\text { Reduced eutrophication in the Baltic } \\
\text { Sea, nutrient recycling }\end{array}$ \\
\hline Reed, coast & Biogas & Biofertilizer & $\begin{array}{l}\text { Reduced eutrophication in the Baltic } \\
\text { Sea, nutrient recycling }\end{array}$ \\
\hline Park and garden waste & Biogas & Biofertilizer & $\begin{array}{l}\text { Biological waste treatment, nutrient } \\
\text { recycling }\end{array}$ \\
\hline Straw & Ethanol & Molasses, Energy production & \\
\hline $\begin{array}{l}\text { Process water, pulp } \\
\text { and paper industry }\end{array}$ & Biogas & & $\begin{array}{l}\text { Biological waste treatment, Reduced } \\
\text { electricity use for aerated cleaning }\end{array}$ \\
\hline Farmed mussels & Biogas & Biofertilizer & $\begin{array}{l}\text { Reduced eutrophication in the Baltic } \\
\text { Sea, nutrient recycling }\end{array}$ \\
\hline
\end{tabular}


Biogas production dominates the assessed biofuel potential (see Table 4), which from a multifunctional perspective is beneficial due to the many opportunities for multifunctionality provided by biogas production systems. However biogas as energy carrier requires larger changes in the current infrastructure compared to biodiesel or ethanol due to its gaseous properties, which can be a barrier especially for small producers. Such aspects have not been fully taken into consideration in this study. 


\section{Connectedness and its dynamics in some Swedish biofuel producers}

This chapter summarizes the results in Paper 2, and they are discussed in relation to the research questions and aim.

To better understand the conditions for biofuel production in Sweden four cases of biofuel producing companies in Sweden representing three different biofuels (ethanol, biodiesel and biogas) have been studied. In the case of biogas two different forms of ownership were also represented: the municipal biogas company $(\mathrm{MBC})$ and the private biogas company $(\mathrm{PBC})$. They are all producing biofuels from mainly Swedish feedstock for the Swedish market and could be regarded as important actors within the biofuel for transport segment. The ethanol (EC) and biodiesel (BDC) producers have operation at one site each while the biogas companies have operation at two and three sites respectively. The focus is on cooperation and dynamics of cooperation since this is relevant regarding resource efficiency (cf. Boons et al., 2011, Wolf and Karlsson, 2008).

The most far-reaching valorisation and diversification plans were found in the ethanol company (EC), thus this case was found especially interesting since it could be seen as a development in the direction of the biorefinery concept assumed to improve environmental and economic performance of biofuel production systems (Fatih Demirbas, 2009). In the BDC the opportunities for valorisation and diversification were smaller although a valuable by-product, rapeseed cake, is produced when producing biodiesel from rapeseed. This is because the biodiesel production in this case is based on pure rapeseed oil delivered through cooperation with a vegetable oil refinery which keeps and refines the rapeseed cake produced when extracting the rapeseed oil. Producing biodiesel from rapeseed oil mainly gives one by-product, glycerol, which can be refined to a more valuable commodity. In the biogas cases most of the feedstock is waste or by-products which are upgraded to valuable products such as fuel and biofertilizer, hence in those cases biogas production might be compared to a waste refinery or an upcycling tenant (cf. Martin, 2010). Biogas production might also be a potentially interesting step to add to "biorefineries".

Because the ethanol company was found especially interesting in relation to RQ2 this case is described more in detail in this cover essay, while the other three cases are more extensively described in Paper 2. The results from the analysis of all four cases are however discussed in section 6.2 and 6.3., which follow. 


\subsection{Business strategies, status and dynamics of connectedness in the ethanol company}

When starting up the ethanol company (EC) in 2001, the business idea was to make ethanol out of grains for the Swedish low-blending petrol market and also to make use of the by-product, the stillage. When selecting a location for the new plant many aspects were considered, but the availability of a large, stable and renewable energy source was one of the most important since ethanol production is energy demanding and the energy system largely influences the environmental performance of the ethanol produced. The cooperation where steam is supplied through a pipeline from the neighbouring CHP plant, connected to the district heating grid and fuelled with solid biofuels and waste, was established at the start-up of the ethanol plant. A large expansion of ethanol production took place in 2008 and the private owners of the CHP plant decided to build a new boiler to meet the increased demand for steam. Today approximately $85 \%$ of the energy demand in the EC is covered through this cooperation. The remaining $15 \%$ is covered by electricity from the grid. The main forms of material and energy cooperations in the EC are illustrated in Figure 6. A well-integrated process for the production of Distillers Dried Grains with Solubles (DDGS) with the ethanol production has developed where an internal reuse of heat has made the process very energy efficient, which is why today only small quantities of residual heat are sent back with the condensate to the CHP plant. Part of the stillage called thin stillage is sent for biogas production to the neighbouring biogas plant. The EC is situated in a district of Sweden with a lot of agricultural land and $80-90 \%$ of the used grains is produced in Sweden and mostly supplied by regional farmers within a radius of $200 \mathrm{~km}$. 


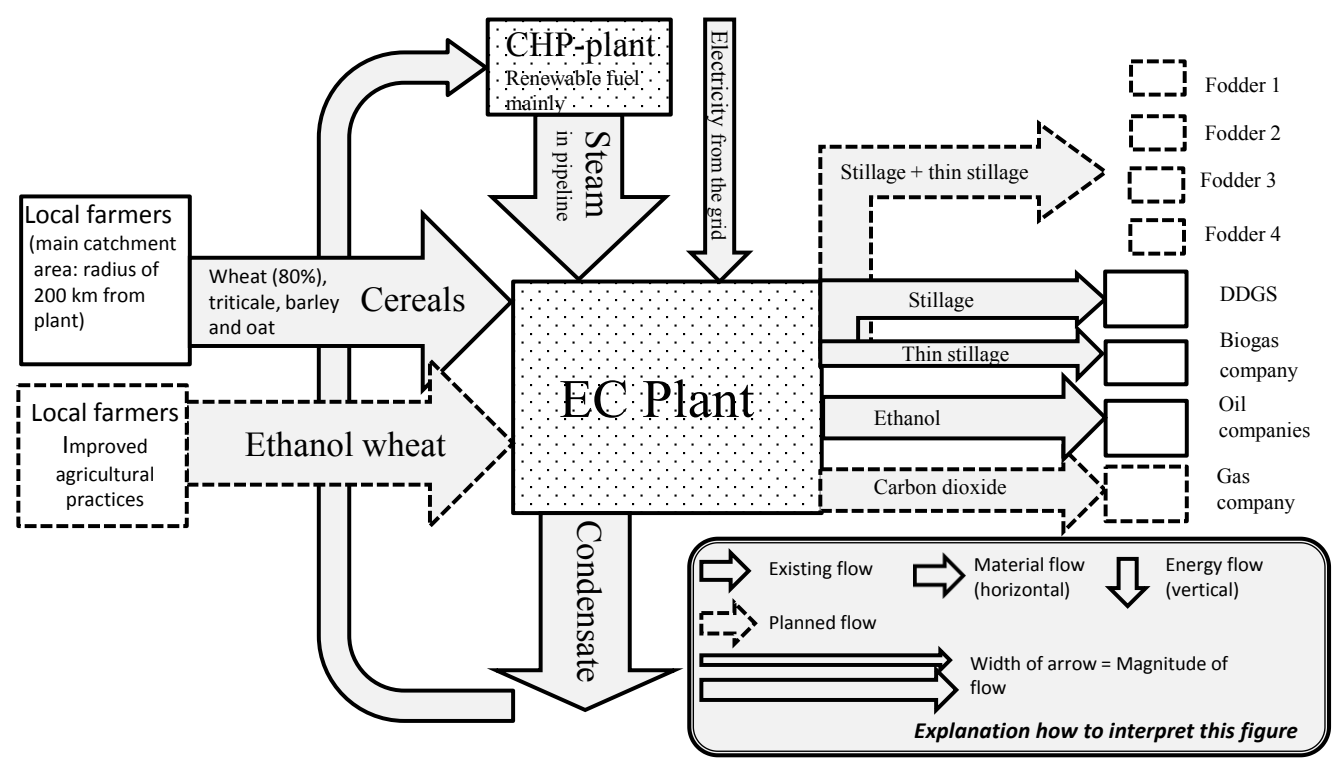

Figure 6. The main exchanges regarding material and energy in the ethanol company (EC) (Paper 2).

The main product, ethanol, is mostly sold for the Swedish market in bulk to "oil companies". With increased prices on grains and increased competition on the ethanol market the economic margins have shrunk for ethanol production in the EC. Simultaneously, however, fodder prices have increased which has benefitted the price development of DDGS which today contributes one-third of the income while ethanol contributes with two-thirds. To lower the price of feedstock the EC has tried to introduce the ethanol wheat concept as a win-win concept to farmers. The concept is about growing a special variety of wheat which is higher yielding but at the same time requires less nitrogen application, implying decreased costs for the farmer. This wheat variety also has a higher starch content benefitting the EC since ethanol is made from the starch. In addition GHG emissions will be reduced due to the reduced nitrogen application which also benefits the EC since the environmental performance will improve. A more radical change in business strategy however is the planned valorisation and diversification strategy for the by-product, the stillage. This strategy requires a larger restructuring of the business organization which will have implications for the resource efficiency of the EC. Since the thin stillage is included in the plans for a diversified fodder production, the cooperation with the biogas producer will have to cease or at least change in some way. Central in this strategy is the idea of valorisation, related to the biorefinery concept, where valuable organic compounds are extracted and refined in order to increase the economic value. Since the EC plant is a fodder plant it is however restricted to the fodder segment and cannot 
compete in markets for even more valuable food products without bigger changes. The EC also plans to cooperate with an external gas company regarding capturing and cleaning $\mathrm{CO}_{2}$ produced in the ethanol process, which is another example of valorising a by-product. The $\mathrm{CO}_{2}$ has a small economic value in relation to the ethanol and stillage, but the GHG emission performance of the ethanol produced could be largely reduced if the $\mathrm{CO}_{2}$ is captured and sold for other applications. Hence, the development in the $\mathrm{EC}$ is mostly business driven, but the environmental driver is also regarded as important for instance in the case of the $\mathrm{CO}_{2}$ cooperation which could be regarded as part of a "green" branding strategy.

\subsection{Status of and dynamics in connectedness}

Regarding cooperation in the studied cases, it is clear that many material and energy cooperative projects exist and involve many actors, such as a number of suppliers of feedstock and energy and several customers of main products as well as by-products. Heat cooperation based on a large share of renewables was the most common form of cooperation found in all companies usually involving two actors in each case, the heat producer and the heat user. By-product cooperation was also common, but the number of actors involved differs depending on the by-products involved, where the exchange of thin stillage and glycerol mainly involve the biogas producers and the biodiesel and ethanol company respectively while the offset of the digestate/biofertilizer and the DDGS involves cooperation with many farmers. In the case of biofertilizer the offset sometimes also involves an external consulting firm organizing the contracting, while the offset of the DDGS is organized within the corporate group of the ethanol producer.

Clearly good relations and well-functioning cooperation with the agricultural sector, including individual farmers, is important for the biofuel producers because much of the supply of feedstock and the offset of by-products relies on this. Existing material flow cooperation projects involved individual farmers as well as agricultural corporation. Other important sectors for cooperation regarding material flows include the food and feed industry supplying or receiving by-products.

The connectedness in the studied companies can be described as dynamic, since there have been changes regarding material and energy flows influencing cooperative structures in all companies during their relatively short time of operation. Business strategies have been revised in order to cope with challenges to stay, or become, competitive and in many cases this has led to a development of a range of cooperation projects of which the most relevant are compiled in Table 5. Most of the exchanges involve material and energy flows, but cooperation involving e.g. information sharing and joint investment projects were also regarded as interesting cooperation projects and thus included in Table 5. According to planned development in the companies these dynamic strategies will continue.

By-product exchanges seem to be most dynamic, especially when there is no shared infrastructure for the exchanges. Due to the shift towards a valorisation and diversification strategy of by-products 
most evident in the EC and to some extent in the BDC, a trend towards reduced by-product exchanges could be seen. The biodiesel producer is considering the option to produce refined glycerol, which has a greater economic value on the market instead of sending the glycerol to a biogas producer. Similarly the ethanol producer is considering the option of refining all of their protein-rich stillage (also including the thin stillage now sent to a biogas producer) into a spectrum of different customized protein fodders in order to increase the economic value of the stillage. This strategy is in line with the biorefinery idea, which means that the most valuable compounds are refined in order to increase the economic value of the products. The biogas producers also display an ambition to valorise the by-product, the biofertilizer. In order to stay competitive it is important for biogas producers to increase the income from this by-product which today often is a zero sum game. However, so far mostly plans in this direction were identified and joint investment projects in research and development for more resource-efficient use of the digestate.

The input of feedstock is diverse for both biogas producers and has changed during their time of operation. There will probably be more changes in the future since according to the plans an important business strategy is to lower cost for feedstock in both companies. The private biogas company plans to increase flexibility regarding feedstock while the municipal biogas company instead focuses on internally available feedstock in the corporate group, such as food waste sorted from household waste, which is controlled by a municipal monopoly. The biogas technology is flexible (Lantz et al., 2007) and enables the use of many different feedstocks, making such a strategy feasible. It is not unproblematic however from a quality or economic perspective since the feedstock is often heterogeneous, which is challenging from a biogas process perspective, and also requires cooperation with many actors.

In the ethanol company and biodiesel company ambitions to lower costs for feedstock were also identified, but due to their specificity in feedstock (cf. Cherubini, 2010a) the room for flexibility in feedstock is smaller. The ethanol wheat concept described in 6.1 above is one possible option for the ethanol company, however involving change of practice among many farmers which can be challenging (cf. Tilman et al., 2002).

The utility cooperations such as the heating and cooling cooperation involving shared infrastructure seems to be the most stable cooperations in the studied cases in similarity to cases studied by for instance van Beers et al. (2007). Some dynamics were noted like the expansion of steam cooperation between the ethanol producer and the CHP plant which lead to the need for an expanded district heating network. Another example regards the application of a new biogas upgrading technology, requiring an expanded district heating cooperation. 


\subsection{Critical factors for connectedness}

The dynamics described above show that the conditions for biofuel production have changed over time in all the studied companies. Business strategies have been developed in order to adapt to the changing conditions in order to stay or become competitive and this has influenced the cooperative structures.

Many of the critical factors for cooperation mentioned by the respondents relates to economic and environmental impact which fits well with the idea that it is relevant to study changes in connectedness (cf. Boons et al., 2011, Karlsson and Wolf, 2008). In order to clarify the relative importance in relation to the different cooperation projects the respondents were asked to rate the environmental and economic drivers. In relation to the result presented in Table 5, it is important to note that the respondents have rated these drivers based on their own interpretation which they did not have to clarify. In the discussion here they both represent economic drivers to some extent; the economic driver however refers to more direct economic implications while the environmental driver refers to more long-term economic implications such as branding.

The critical factors for cooperation on heat varied to some extent, but policy is mentioned in all cases and in this case mainly refers to the EU RES requiring reduced GHG emissions making the energy system important due to its big impact on the GHG emissions of biofuel production (cf. Börjesson, 2009). Both the environmental and the economic driver for such cooperation projects were rated strong indicating that energy cooperation projects are important for all the companies.

From Table 5 it could also be seen that by-products from the biofuel industry such as thin stillage and glycerol, serves as feedstock for biogas production in several cases which can lead to improved environmental performance of the biofuels (Martin and Eklund, 2011). However, in all cases of such cooperation, policy was considered a constraining critical factor, which according to the respondents is due to the allocation method dictated in the EU RES. The allocation method implies that only the receiver benefits in cases of such by-product cooperation projects (cf. Tufvesson et al., 2013). However, policy in this case was not regarded as one of the most important critical factors. Instead the low economic driver was emphasized by the respondents. Hence the importance of the economic driver for such cooperation projects seems to have changed, compared to when the thin stillage and glycerol cooperation came about, and could be related to the new valorisation and diversification strategies found in the EC as well as in the BDC.

The biogas producers also expressed a wish to valorise and diversify the by-product, the biofertilizer, for which profit has been very low (up to $2 \%$ of the profit in the PBC). Among the critical factors for biofertilizer cooperation nutrient recycling was mentioned, which is an important national environmental goal. However, with the low economic driver, the contribution to this goal by the biogas producers must be regarded as vulnerable, especially since the respondents did not have any concrete plans for how to improve the economic performance of the biofertilizer cooperation in the short term. 
General problems of staying competitive were pointed at by all respondents in this study and ways to improve profitability were searched for by the companies. In the two biogas cases, a strategy to lower feedstock costs was identified as closer to realization than the diversification and valorisation strategy found in the EC and BDC. This development was due to a general experience of increased competition for biogas feedstock and consequentially increasing prices. The strategy to find more cost-efficient feedstock motivated new investments and more administration to increase the capacity to be flexible regarding feedstock.

A big cost for biofuel producers of biogas and pure biodiesel has been to keep the market and infrastructure development in pace with an upscaled production. The BDC is still struggling with building a market and an infrastructure for pure biodiesel besides the production of biodiesel. Today however contracts on biogas can be made with a gas sales and distribution company which is the strategy of the private biogas company. The municipal biogas company still organizes most of their own biogas distribution, but according to their plans they might separate the sales and distribution from production in order to focus on their core business, biogas production. Another benefit of such a strategy would be that it would increase the possibilities for the sales and distribution company to cooperate with other partners such as small-scale or rural biogas producers, since they would not be restricted by municipal regulations if turned into a private company. 
Table 5. Summary of cooperations in the Ethanol Company (EC), Biodiesel Company (BDC), Municipal Biogas Company (MBC) and the Private Biogas Company ( $P B C)$ (see Paper 2 for extensive Tables).

\begin{tabular}{|c|c|c|c|c|}
\hline Cooperation projects & $\begin{array}{l}\text { Com } \\
\text { pany }\end{array}$ & Critical factors & $\begin{array}{l}\text { Eco- } \\
\text { nomic } \\
\text { driver }^{3}\end{array}$ & $\begin{array}{l}\text { Environ- } \\
\text { mental } \\
\text { driver }^{3}\end{array}$ \\
\hline Green $^{1}$ steam from CHP pipeline & $\mathrm{EC}$ & availability, policy ${ }^{2}$, pipeline & $* * *$ & $* * *$ \\
\hline Thin stillage to biogas & $\mathrm{EC}$ & alternative offset, business agreement, policy & * & * \\
\hline Stillage to DDGS & $\mathrm{EC}$ & profitability fodder, rest heat, policy & *** & ** \\
\hline Local farmers & $\mathrm{EC}$ & reduced transport, relation $\&$ trust, policy & * & ** \\
\hline Diversified fodder production & $\mathrm{EC}$ & valorisation by-product, in-house competency, investment & $* * *$ & $* *$ \\
\hline Ethanol wheat & $\mathrm{EC}$ & cheaper feedstock, policy, tradition & $* *$ & $* * *$ \\
\hline $\mathrm{CO}_{2}$ capture and cleaning & $\mathrm{BDC}$ & policy, economic risk, business agreement & * & $* * *$ \\
\hline $\begin{array}{l}\text { Green steam from Vegetable Oil } \\
\text { Refinery (pipeline) }\end{array}$ & $\mathrm{BDC}$ & policy, relations \& trust, investment, pipeline & $* * *$ & $* * *$ \\
\hline $\begin{array}{l}\text { Rapeseed oil from Vegetable Oil } \\
\text { Refinery (pipeline) }\end{array}$ & BDC & major customer benefits, relation \& trust, policy, pipeline & $* *$ & $* * *$ \\
\hline Glycerol to biogas & $\mathrm{BDC}$ & business agreement, relations \& trust, policy & * & $* *$ \\
\hline Refined glycerol & $\mathrm{BDC}$ & valorisation by-product, policy, economic risk & $* *(*)$ & ** \\
\hline $\begin{array}{l}\text { Used Cooking Oil from } \\
\text { customers }\end{array}$ & BDC & business agreement, relation \& trust, policy & $* *$ & $* * *$ \\
\hline $\begin{array}{l}\text { Joint investment filling stations } \\
\text { with truck manufacturer }\end{array}$ & $\mathrm{BDC}$ & Business agreement, mutual goodwill, investment & $* *$ & $\mathrm{n} / \mathrm{a}$ \\
\hline $\begin{array}{l}\text { Green heat via district heating } \\
\text { grid (one site) }\end{array}$ & MBC & $\begin{array}{l}\text { Intra-firm business agreement, available district heating } \\
\text { grid, policy }\end{array}$ & $* * *$ & $* * *$ \\
\hline $\begin{array}{l}\text { Industrial food waste (e.g. } \\
\text { slaughter house waste) }\end{array}$ & MBC & waste service, gate fee, policy, relations \& trust & $* * *$ & $* * *$ \\
\hline $\begin{array}{l}\text { Thin stillage from ethanol } \\
\text { production to biogas (one site) }\end{array}$ & $\mathrm{MBC}$ & specialized plant, not price competitive, policy & $*$ & $* *$ \\
\hline Digestate to biofertilizer & MBC & $\begin{array}{l}\text { large quantities, expensive storage and distribution, nutrient } \\
\text { recycling, national environmental goals }\end{array}$ & * & $* * *$ \\
\hline Food waste households & MBC & $\begin{array}{l}\text { National environmental.goals, heterogeneity, gate fee, } \\
\text { monopoly, relation \& trust }\end{array}$ & $* *$ & $* * *$ \\
\hline $\begin{array}{l}\text { Split company production \& } \\
\text { selling/ distribution }\end{array}$ & $\mathrm{MBC}$ & $\begin{array}{l}\text { Focus on core business, regulations municipal companies, } \\
\text { decentralized production, cooperation around feedstock }\end{array}$ & ** & $\mathrm{n} / \mathrm{a}$ \\
\hline $\begin{array}{l}\text { Green heat from biofuelled farm } \\
\text { boiler (one site) }\end{array}$ & PBC & windows of opportunity, policy, relations \& trust & $* * *$ & $* * *$ \\
\hline $\begin{array}{l}\text { Industrial food waste (in need of } \\
\text { hygienization) }\end{array}$ & PBC & waste service, policy, relations \& trust, co-digestion benefits & *** & $* * *$ \\
\hline Other Industrial food by-products & PBC & Policy, green marketing, competition, relation \& trust & * & $* * *$ \\
\hline $\begin{array}{l}\text { Glycerol from biodiesel } \\
\text { production }\end{array}$ & $\mathrm{PBC}$ & $\begin{array}{l}\text { Efficient process regulator substrate, policy, not price } \\
\text { competitive, relation \& trust }\end{array}$ & * & $* *$ \\
\hline $\begin{array}{l}\text { Dedicated (ley) crops for biogas } \\
\text { production }\end{array}$ & PBC & $\begin{array}{l}\text { low profitability, potentially large availability, policy, } \\
\text { improved agricultural practices }\end{array}$ & * & $*$ \\
\hline Pig manure & PBC & $\begin{array}{l}\text { Low energy content, high availability, policy, barter ex- } \\
\text { change manure/bio fertilizer }\end{array}$ & $* *$ & $* * *$ \\
\hline Digestate to biofertilizer & PBC & $\begin{array}{l}\text { large quantities, expensive storage \& distribution, relation \& } \\
\text { trust, nutrient recycling (environmental goals) }\end{array}$ & $*$ & $* * *$ \\
\hline $\begin{array}{l}\text { Gas sales and distributing } \\
\text { company }\end{array}$ & $\mathrm{PBC}$ & $\begin{array}{l}\text { Secured market and fixed price, simplicity, access to new } \\
\text { technology }\end{array}$ & $* *$ & $\mathrm{n} / \mathrm{a}$ \\
\hline Flexibility on feedstock & $\mathrm{PBC}$ & $\begin{array}{l}\text { Cost efficient, investment, policy, relations \& trust, requires } \\
\text { administration }\end{array}$ & $* * *$ & $* *$ \\
\hline
\end{tabular}




\section{Conclusions}

In this chapter answers to the research questions are given and also a synthesis.

The conditions for producing resource-efficient biofuels for transport in Sweden was approached from a regional resource focused perspective as well as a biofuel producer perspective. From the regional resource focused perspective a biofuel for transport potential in the Swedish region of Östergötland was assessed, potentially covering $30-50 \%$ of the estimated energy needs for transportation, depending on scenario, in 2030. The assessment was a step wise iterative process with the region of Östergötland in focus. It stretched from categorizing feedstock sectors, selecting relevant feedstocks, assuming available shares of each feedstock, estimating energy potentials in relation to selected energy carriers to estimating the number of new biofuel production plants that would be needed to realize part of the potential. The sketched-out estimation of plants was a way to approach the challenges of implementation where the establishment of new plants is considered to be a barrier in the rapid up-scaling that would be required to realize the assessed biofuel potential by 2030. The assessed biofuel potential included a large share of secondary products and by-products and considerations were also made regarding other needs and additional benefits, which is why the potential at least from these perspectives could be considered as resource efficient. However, the resource efficiency of biofuels is also largely dependent on the production system, e.g. the choice of energy system and how by-products are used, which will only be determined if the potential is realized. Regarding realization of the biofuel potential it could be concluded that it would also require extensive cooperation between many actors in society at different levels which would go far beyond what is practice today.

The conditions for producing resource-efficient biofuels were approached by studying four biofuel companies in Sweden. During the relatively short time of existence the studied companies have changed in terms of business strategies and cooperative structure to adapt to changed conditions for being competitive and producing biofuels for the Swedish market. All studied cases have been largely dynamic regarding how they organize their biofuel production in terms of material and energy flows. They have made efforts to become more resource efficient including reaching economic viability partly through cooperation projects. In most cases this has increased the level of connectedness in the studied companies due to an expansion of the current cooperation projects, but also by introducing new ones.

Looking into the future, the described business strategies in the studied companies seem to imply changes regarding by-product cooperation. Valorisation and diversification strategies identified in the ethanol and biodiesel producers will benefit internal use of by-products ahead of the current inter-firm exchanges of these by-products to biogas producers. The central ideas in these strategies relate to the biorefinery concept, where valuable compounds are extracted and refined into more valuable products potentially increasing the economic viability and resource efficiency of the production. 
The biogas producers aim for using more low-quality feedstock, having a lower price. In the long run this could lead to even greater diversity regarding feedstock for biogas production, potentially beneficial for resilience and resource efficiency. However, a challenge in relation to biogas production is how to make the digestate/biofertilizer a more attractive product for which the willingness to pay is higher.

Critical factors for existing cooperation projects identified in the companies were diverse, but the EU RES directive was mentioned in most cases, and thus considered one of the most important critical factors. The EU RES was mainly regarded as an environmental driver by the actors although in Sweden it is linked to a tax exemption on biofuels, hence it is also a direct economic incentive. The companies still had ambitions to continue to improve their environmental performance although all the studied companies met the sustainability criteria in the EU RES. This environmental ambition however could probably be seen as a reflection of a more long-term strategy for green branding, since most biofuel producers also experience pressure from the market to further contribute to sustainability.

The studied companies have shown dynamism over time regarding cooperative structures and ability to cope with challenges, which could be interpreted as a willingness and capacity to change and adapt to varying conditions. The biofuel production industry might have to move towards higher diversity and more dynamics regarding connectedness in order to be competitive in the future. This will benefit resilience which according to $\mathrm{Mu}$ et. al. (2011) is especially important in biofuel production systems and leads to better resource efficiency.

Such development is also in line with the EU growth strategy and the ambitions to move towards a "greener", bio-based economy where biorefineries are expected to deliver an array of valuable products in a resource-efficient way. This development is related to the production of better biofuels, i.e. more resource efficient, but not necessarily to more biofuels since one barrier is a lack of competitively priced feedstock. In order to also get more biofuels it is necessary that new feedstock is made easily available for biofuel production. There is also a need for actors with a capacity to seize opportunities arising regarding unconventional feedstock. Both biogas companies studied here have shown capacity to partly pick up new feedstock, and even if in both cases this concerns conventional feedstock to some extent this is an important feature of future resourceefficient biofuel production systems.

An ambition to push for the use of new biofuel feedstock, preferentially secondary material or material requiring low land use, could also be identified in the approved proposal (EU RES, 2012) amending the EU RES Directive (EU RES, 2009) and the Fuel Quality Directive (European Parliament, 1998). How the ambitions can be met by the biofuel producers will however depend largely on the final enactment of provisions in this amendment and the adoption of measures on a national level. 


\section{Future research}

In this chapter ideas for future research are presented.

In relation to the biofuel potential there are many aspects that need to be further analysed in order to approach a road map for realization.

Studies that could contribute to such road map could be:

- Assessment studies considering more site specific conditions for certain feedstock for which data from literature was used for estimation, concerning e.g. algae and reed

- Evaluation studies of technical feasibility of collection/sorting options for different feedstock

- Full LCA studies to better assess the environmental performance for some of the unconventional feedstock for which generic figures or estimations were used to assess a GHG reduction potential

- Evaluation of production plants from a co-digestion perspective (biogas production systems) considering localization, size, technology, energy system etc.

- Evaluation of the biofuel potential from a 'biorefinery' and integration perspective (cf. Octave and Thomas, 2009, Ekman, 2012) (ethanol and biodiesel production systems)

- Further analysis of how actors adapt to biofuel policy and policy changes and how this influences the production as well as the environmental and economic performance of the biofuels.

Additionally, studies specifically focusing on biogas production systems are suggested since they seem interesting in relation to resource efficiency. Especially studies focusing on the feasibility related to the flexibility and complexity of the biogas production systems (cf. Börjesson and Mattiasson, 2008) seem relevant, for instance studies regarding:

- Barriers and drivers for nutrient recycling via biofertilizer use

- Barriers and drivers for cooperation around unconventional feedstock

- Barriers and drivers for cooperation with the agricultural sector, e.g. around production of multifunctional feedstock

Related research is ongoing within the Biogas Research Center (BRC) at Linköping University and the examples above fits well into the scope of some existing projects. 


\section{References}

AEBIOM. 2009. A biogas roadmap for Europe [Online]. European Biomass Association. Available: http://www.aebiom.org/IMG/pdf/Brochure_BiogasRoadmap_WEB.pdf [Accessed 12th of February 2014].

BAAS, L. W. 2005. Cleaner production and industrial ecology: Dynamic aspects of the introduction and dissemination of new concepts in industrial practice, Eburon Uitgeverij BV.

BAGLIANI, M., DANSERO, E. \& PUTTILLI, M. 2010. Territory and energy sustainability: The challenge of renewable energy sources. Journal of Environmental Planning and Management, 53, 457-472.

BENJAMINSSON, J. \& LINNÉ, M. 2007. Biogasanläggningar med $300 \mathrm{GWh}$ årsproduktion - system, teknik och ekonomi. SGC.

BERGLUND, M. \& BÖRJESSON, P. 2006. Assessment of energy performance in the life-cycle of biogas production. Biomass and Bioenergy, 30, 254-266.

BERNDES, G., HOOGWIJK, M. \& VAN DEN BROEK, R. 2003. The contribution of biomass in the future global energy supply: A review of 17 studies. Biomass and Bioenergy, 25, 1-28.

BOONS, F. \& LÜDEKE-FREUND, F. 2013. Business models for sustainable innovation: state-of-the-art and steps towards a research agenda. Journal of Cleaner Production, 45, 9-19.

BOONS, F. \& MENDOZA, A. 2010. Constructing sustainable palm oil: how actors define sustainability. Journal of Cleaner Production, 18, 1686-1695.

BOONS, F., SPEKKINK, W. \& MOUZAKITIS, Y. 2011. The dynamics of industrial symbiosis: a proposal for a conceptual framework based upon a comprehensive literature review. Journal of Cleaner Production, 19, 905-911.

BP 2012. BP Energy Outlook 2030. London: British Petroleum Company.

BRYMAN, A. 2002. Samhällsvetenskapliga metoder, Liber Ekonomi.

BÖRJESON, L., HÖJER, M., DREBORG, K-H., EKVALL, T., FINNVEDEN, G. 2006. Scenario types and techniques: Towards a user's guide. Futures, 38, 723-739.

BÖRJESSON, P. 2009. Good or bad bioethanol from a greenhouse gas perspective - What determines this? Applied Energy, 86, 589-594.

BÖRJESSON, P. \& BERGLUND, M. 2006. Environmental systems analysis of biogas systems-Part I: Fuelcycle emissions. Biomass and Bioenergy, 30, 469-485.

BÖRJESSON, P. \& BERNDES, G. 2006. The prospects for willow plantations for wastewater treatment in Sweden. Biomass and Bioenergy, 30, 428-438.

BÖRJESSON, P. \& MATTIASSON, B. 2008. Biogas as a resource-efficient vehicle fuel. Trends in Biotechnology, 26, 7-13.

BÖRJESSON, P. \& TUFVESSON, L. M. 2011. Agricultural crop-based biofuels - resource efficiency and environmental performance including direct land use changes. Journal of Cleaner Production, 19, 108-120.

CHERTOW, M. R. 2000. Industrial symbiosis: Literature and taxonomy. Annual Review of Energy and the Environment, 25, 313-337.

CHERTOW, M. R. \& LOMBARDI, D. R. 2005. Quantifying Economic and Environmental Benefits of CoLocated Firms. Environmental Science \& Technology, 39, 6535-6541.

CHERUBINI, F. 2010a. The biorefinery concept: Using biomass instead of oil for producing energy and chemicals. Energy Conversion and Management, 51, 1412-1421.

CHERUBINI, F. 2010b. GHG balances of bioenergy systems - Overview of key steps in the production chain and methodological concerns. Renewable Energy, 35, 1565-1573.

CHERUBINI, F., BIRD, N. D., COWIE, A., JUNGMEIER, G., SCHLAMADINGER, B. \& WOESS-GALLASCH, S. 2009. Energy- and greenhouse gas-based LCA of biofuel and bioenergy systems: Key issues, ranges and recommendations. Resources, Conservation and Recycling, 53, 434-447. 
CÔTÉ, R. P. \& COHEN-ROSENTHAL, E. 1998. Designing eco-industrial parks: a synthesis of some experiences. Journal of Cleaner Production, 6, 181-188.

DAUTZENBERG, K. \& HANF, J. 2008. Biofuel chain development in Germany: Organisation, opportunities, and challenges. Energy Policy, 36, 485-489.

DE WILT, J. 2008. Ecopyramid: Proper utilization of biomass! Concept guide. InnovatienNetwerk.

DE WIT, M., JUNGINGER, M., LENSINK, S., LONDO, M. \& FAAIJ, A. 2010. Competition between biofuels: Modeling technological learning and cost reductions over time. Biomass and Bioenergy, 34, 203217.

DOMAC, J., SEGON, V., PRZULJ, I. \& RAJIC, K. 2011. Regional energy planning methodology, drivers and implementation - Karlovac County case study. Biomass and Bioenergy, 35, 4504-4510.

EHRENFELD, J. R. 2005. Eco-efficiency: Philosophy, Theory, and Tools. Journal of Industrial Ecology, 9, 68.

EKLUND, M. 2010. Industrial symbiosis for the sustainable use of biofuels. Biofuels, 1, 373-375.

EKMAN, A. 2012. Environmental Assessment of Emerging Bio-based Production - Possibilites in a future Bio-economy. Lund university, Environment and Energy Systems Studies. Lund: Lund University.

ENERGIMYNDIGHETEN 2013. Kortsiktsprognos över energianvändning och energitillförsel 2013-2015 Energimyndigheten.

ERICSSON, K., ROSENQVIST, H. \& NILSSON, L. J. 2009. Energy crop production costs in the EU. Biomass and Bioenergy, 33, 1577-1586.

ERKMAN, S. 1997. Industrial ecology: An historical view. Journal of Cleaner Production, 5, 1-10.

ERSSON, C., EKLUND, M., AMMENBERG, J. \& IVNER, J. 2012. Vision för biodrivmedel i Östergötland Tillgång på regionala råvaror och principer för en resurseffektiv produktion år 2030. Linköping university.

ESTY, D. \& PORTER, M. 1998. Industrial Ecology and Competitiveness - Strategic Implications for the firm Journal of Industrial Ecology, 2.

EU RES 2009. Directive 2009/28/EC of the European Parliament and of the Council of 23 April 2009 on the promotion of the use of energy from renewable sources and amending and subsequently repealing Directives 2001/77/EC and 2003/30/EC.

EU RES 2012. Proposal for a Directive of the European Parliament and of the Council amending Directive 98/70/EC relating to the quality of petrol and diesel fuels and amending Directive 2009/28/EC on the promotion of the use of energy from renewable sources. European Parliament.

EUROPEAN ACADEMIES SCIENCE ADVISORY COUNCIL. 2012. The current status of biofuels in the European Union, their environmental impacts and future prospects. EASAC.

EUROPEAN COMMISSION 2011. Energy roadmap 2050.

EUROPEAN COMMISSION. 2014. EU response to the crisis [Online]. European Commission. Available: http://ec.europa.eu/economy_finance/crisis/index_en.htm [Accessed 2nd of February 2014].

EUROPEAN COMMISSION. 2012. Innovating for Sustainable Growth: A Bioeconomy for Europe. In: EUROPEAN COMMISSION. (ed.). Brussels: European Union.

EUROPEAN PARLIAMENT 1998. Directive 98/70/EC of the European Parliament and of the Council of 13 October 1998 relating to the quality of petrol and diesel fuels and amending Council Directive 93/12/EEC.

EUROSTAT. 2013. Statistics database [Online]. European Commission. Available: http://epp.eurostat.ec.europa.eu/portal/page/portal/statistics/search_database [Accessed 9th of October 2013.

EUROSTAT 2014. Greenhouse gas emissions by source sector 1990 and 2010. European Commission.

EXXON MOBIL 2013. The outlook for energy - a view to 2040.

FATIH DEMIRBAS, M. 2009. Biorefineries for biofuel upgrading: A critical review. Applied Energy, 86, Supplement 1, S151-S161. 
FEIZ, R., AMMENBERG, J., BAAS, L., EKLUND, M., HELGSTRAND, A. \& MARSHALL, R. 2013. Improving the $\mathrm{CO} 2$ performance of cement, part II: Framework for assessing $\mathrm{CO} 2$ improvement measures in cement industry. . Manuscript submitted to the Journal of Cleaner Production.

FISCHER, G., PRIELER, S., VAN VELTHUIZEN, H., BERNDES, G., FAAIJ, A., LONDO, M. \& DE WIT, M. 2010. Biofuel production potentials in Europe: Sustainable use of cultivated land and pastures, Part II: Land use scenarios. Biomass and Bioenergy, 34, 173-187.

GASBILEN. 2014. Tankställen [Online]. Gasbilen. Available: http://www.gasbilen.se/Att-tanka-dingasbil/Tankstallen [Accessed 26th of February 2014].

GRAEDEL, T. E. \& ALLENBY, B. R. 2010. Industrial Ecology and Sustainable Engineering, Pearson/Prentice Hall.

HABERL, H., ERB, H. K., KRAUSMANN, F., GAUBE, V., BONDEAU, A., PLUTZAR, C., GINGRICH, S., LUCHT, W. \& FISCHER-KOWALSKI, M. 2007. Quantifying and mapping the human appropriation of net primary production in earth's terrestial ecosystems. PNAS, 104, 12942-12947.

HANSSON, A., TJERNSTRÖM, E., GRADIN, M. \& FINNIS, P. 2012. Wetlands Algae Biogas - A Southern Baltic Sea Eutrophication Counteract Project. Trelleborg.

HARDY, C. \& GRAEDEL, T. E. 2002. Industrial Ecosystems as Food Webs. Journal of Industrial Ecology, 6.

HETTINGA, W. G., JUNGINGER, H. M., DEKKER, S. C., HOOGWIJK, M., MCALOON, A. J. \& HICKS, K. B. 2009. Understanding the reductions in US corn ethanol production costs: An experience curve approach. Energy Policy, 37, 190-203.

HOLME, I. \& SOLVANG, B. 1996. Forskningsmetodik, Studentlitteratur.

HOOGWIJK, M. 2004. On the global and regional potential of renewable energy. PhD Dissertation, University of Utrecht.

HÖGLUND, J., AHLGREN, S., GRAHN, M. \& SUNDBERG, C., ET AL 2013. Biofuels and Land Use in Sweden An Overview of Land-Use Change Effects.: f3 The Swedish Knowledge Centre for Renewable Transportation Fuels, Sweden.

IGLIŃSKI, B., BUCZKOWSKI, R., IGLIŃSKA, A., CICHOSZ, M., PIECHOTA, G. \& KUJAWSKI, W. 2012. Agricultural biogas plants in Poland: Investment process, economical and environmental aspects, biogas potential. Renewable and Sustainable Energy Reviews, 16, 4890-4900.

INTERNATIONAL ENERGY AGENCY. 2011. World final energy consumption 2011 [Online]. IEA. Available: http://www.iea.org/Sankey/index.html\#?c=World\&s=Final\%20consumption [Accessed 3rd of December 2013 2013].

ISENMANN, R. 2003. Further efforts to clarify industrial ecology's hidden philosophy of nature. Journal of Industrial Ecology, 6, 27-48.

JACOBSEN, N. B. 2009. Industrial Symbiosis: A potential model for creating more sustainable industrial districts? PhD Dissertation, Roskilde University.

JOKELA, B. Cropping system effects on soil quality. Wisconsin Crop Management Conference 2011, 2011 Madison, Wisconsin. http://www.soils.wisc.edu/extension/wcmc/.

JOKELA, B., RUSSELLE, M. 2009. Perennial forages benefit soils, other crops, and water quality in important ways. In: AGRICULTURE, U. S. D. O. (ed.). Marshfield, Wi: USDA-Agricultural Reserach Service.

KARLSSON, A. 2010. Befolkningsprognoser för Östergötlands län och kommuner samt Tranås kommun åren 2010-2030 (Östsam). Statistics Sweden (SCB).

KARLSSON, M. \& WOLF, A. 2008. Using an optimization model to evaluate the economic benefits of industrial symbiosis in the forest industry. Journal of Cleaner Production, 16, 1536-1544.

KAUTTO, N. \& PECK, P. 2012. Regional biomass planning - Helping to realise national renewable energy goals? Renewable Energy, 46, 23-30.

LAM, H. L., VARBANOV, P. S. \& KLEMEŠ, J. J. 2011. Regional renewable energy and resource planning. Applied Energy, 88, 545-550. 
LANTZ, M. 2013. Biogas in Sweden - Opportunities and challenges from a systems perspectiv. PhD Dissertation, Lund University.

LANTZ, M. \& BJÖRNSSON, L. 2011. Biogas från gödsel och vall - Analys av föreslagna styrmedel. Envirum $A B$ - LRF.

LANTZ, M., SVENSSON, M., BJÖRNSSON, L. \& BÖRJESSON, P. 2007. The prospects for an expansion of biogas systems in Sweden - Incentives, barriers and potentials. Energy Policy, 35, 1819-1829.

LOMBARDI, D. R. \& LAYBOURN, P. 2012. Redefining Industrial Symbiosis. Journal of Industrial Ecology, 16, 28-37.

LOWE, E. A. \& EVANS, L. K. 1995. Industrial ecology and industrial ecosystems. Journal of Cleaner Production, 3, 47-53.

LUCIA, L. D. 2012. Public Policy and the Governance of biofuel systems. PhD Dissertation, Lund University.

MALINS, C. 2013. A model-based quantitative assessment of the carbon benefits of introducing iLUC factors in the European Renewable Energy Directive. GCB Bioenergy, 5, 639-651.

MANGOYANA, R. B. \& SMITH, T. F. 2011. Decentralised bioenergy systems: A review of opportunities and threats. Energy Policy, 39, 1286-1295.

MARTIN, M. 2010. Industrial Symbiosis for the Development of Biofuel Production. Licentiate thesis, Linköping University.

MARTIN, M. 2013. Industrial Symbiosis in the Biofuel Industry: Quantification of the Environmental Performance and Identification of Synergies. PhD dissertation, Linköping University.

MARTIN, M. \& EKLUND, M. 2011. Improving the environmental performance of biofuels with industrial symbiosis. Biomass and Bioenergy, 35, 1747-1755.

MARTIN, M., SVENSSON, N., FONSECA, J. \& EKLUND, M. 2014. Quantifying the environmental performance of integrated bioethanol and biogas production. Renewable Energy, 61, 109-116.

MERRIAM, S. B. 1994. Fallstudien som forskningsmetod, Lund, Studentlitteratur.

MIGNON, I. 2014. Entering renewable electricity production: An actor perspective. Licentiate thesis, Linköping University.

MINISTRY OF INDUSTRY EMPLOYMENT AND COMMUNICATIONS 2012. Fossiloberoende fordonsflotta ett steg på vägen mot nettonollutsläpp av växthusgaser. In: MINISTRY OF INDUSTRY EMPLOYMENT AND COMMUNICATIONS (ed.). Statens Offentliga Utredningar

MIRATA, M., NILSSON, H. \& KUISMA, J. 2005. Production systems aligned with distributed economies: Examples from energy and biomass sectors. Journal of Cleaner Production, 13, 981-991.

MU, D., SEAGER, T. P., RAO, P. S. C., PARK, J. \& ZHAO, F. 2011. A Resilience perspective on biofuel production. Integrated Environmental Assessment and Management, 7, 348-359.

MUSSGNUG, J. H., KLASSEN, V., SCHLÜTER, A. \& KRUSE, O. 2010. Microalgae as substrates for fermentative biogas production in a combined biorefinery concept. Journal of Biotechnology, 150, 51-56.

NILSSON, L. J., JOHANSSON, B., ÅSTRAND, K., ERICSSON, K., SVENNINGSSON, P., BÖRJESSON, P. \& NEIJ, L. 2004. Seeing the wood for the trees: 25 years of renewable energy policy in Sweden. Energy for Sustainable Development, 8, 67-81.

NÄYHÄ, A. \& PESONEN, H.-L. 2012. Diffusion of forest biorefineries in Scandinavia and North America. Technological Forecasting and Social Change, 79, 1111-1120.

OCTAVE, S. \& THOMAS, D. 2009. Biorefinery: Toward an industrial metabolism. Biochimie, 91, 659-664.

OECD/FAO 2012. OECD-FAO Agricultural Outlook 2012-2021,

OFFERMANN, R., SEIDENBERGER, T., THRÄN, D., KALTSCHMITT, M., ZINOVIEV, S. \& MIERTUS, S. 2011. Assessment of global bioenergy potentials. Mitigation and Adaptation Strategies for Global Change, 16, 103-115.

PANZAR, J. C. \& WILLIG, R. D. 1977. ECONOMIES OF SCALE IN MULTI-OUTPUT PRODUCTION. Quarterly Journal of Economics, 91, 481-493. 
PANZAR, J. C., WILLIG, R. D., 1981. Economies of Scope. The American Economic Review, 71, 268-272.

PONTON, J. W. 2009. Biofuels: Thermodynamic sense and nonsense. Journal of Cleaner Production, 17, 896-899.

REGERINGSKANSLIET 1994. Lag (1994:1776) om skatt på energi. In: FINANSDEPARTEMENTET S2 (ed.) SFS 2013:371 ed.

REGERINGSKANSLIET 2013. Sveriges andra rapport om utvecklingen av förnybar energi enligt artikel 22 i Direktiv 2009/28/EG.: Näringskansliet.

REIJNDERS, L. \& HUIJBREGTS, M. A. J. 2011. Nitrous oxide emissions from liquid biofuel production in life cycle assessment. Current Opinion in Environmental Sustainability, 3, 432-437.

REN21 - RENEWABLE ENERGY POLICY NETWORK FOR THE 21ST CENTURY 2013. Renewables 2013 Global status report. In: LISA MASTNY, E. W. I. (ed.). Paris: REN21-Renewable Energy Policy Network for the 21st century.

RICHARD, T. 2012. Ask the Experts: The food versus fuel debate. Biofuels, 3, 635-648.

RIKSREVISIONEN 2011. Biodrivmedel för bättre klimat - Hur används skattebefrielsen?

RUTH, M. \& DAVIDSDOTTIR, B. 2009. The dynamics of regions and networks in industrial ecosystems : background and concepts. The Dynamics of Regions and Networks in Industrial Ecosystems. Edward Elgar Publishing.

SINGH, A., NIGAM, P. S. \& MURPHY, J. D. 2011. Renewable fuels from algae: An answer to debatable land based fuels. Bioresource Technology, 102, 10-16.

SMEETS, E., FAAIJ, A., LEWANDOWSKI, I. \& TURKENBURG, W. 2007. A bottom-up assessment and review of global bio-energy potentials to 2050. Progress in Energy and Combustion Science, 33, 56-106.

SOKKA, L. 2011. Local systems, global impacts : Using life cycle assessment to analyse the potential and constraints of industrial symbioses.

STAKE, R. E. 1995. The Art of Case Study Research, Sage Publications.

SWEDISH BIOENERGY ASSOCIATION (SVEBIO). 2012. Fakta om bioenergi [Online]. Svebio. Available: http://www.svebio.se/fakta-om-bioenergi [Accessed Accessed 12 November 2012.

SWEDISH ENERGY AGENCY 2011. Transportsektorns energianvändning. ES 2011:05. Energimyndigheten.

SWEDISH ENERGY AGENCY 2012. Transportsektorns energianvändning 2011.

SWEDISH ENERGY AGENCY 2013. Hållbara biodrivmedel och flytande biobränslen under 2012.

SWEDISH ENVIRONMENTAL PROTECTION AGENCY 2013. National Inventory Report Sweden 2013 Greenhouse Gas Emission Inventories 1990-2011 - Submitted under the United Nations Framework Convention on Climate Change and the Kyoto Protocol. Swedish Environmental Protection Agency.

SWEDISH PALIAMENT 2009. Pumplagen - Uppföljning av lagen om skyldighet att tillhandahålla förnybara drivmedel. Traffic committee.

SVERIGES RIKSDAG 2013. Lag om kvotplikt för biodrivmedel. In: NÄRINGSDEPARTEMENTET (ed.). Svensk författningssamling: Regeringskansliet/Lagrummet.

TILMAN, D., CASSMAN, K. G., MATSON, P. A., NAYLOR, R. \& POLASKY, S. 2002. Agricultural sustainability and intensive production practices. Nature, 418, 671-677.

TILMAN, D., SOCOLOW, R., FOLEY, J. A., HILL, J., LARSON, E., LYND, L., PACALA, S., REILlY, J., SEARCHINGER, T., SOMERVILLE, C. \& WILLIAMS, R. 2009. Beneficial Biofuels-The Food, Energy, and Environment Trilemma. SCIENCE, 325.

TROST, J. 2010. Kvalitativa intervjuer, Lund, Studentlitteratur.

TUFVESSON, L. M., LANTZ, M. \& BÖRJESSON, P. 2013. Environmental performance of biogas produced from industrial residues including competition with animal feed - life-cycle calculations according to different methodologies and standards. Journal of Cleaner Production, 53, 214-223.

U.S. ENERGY INFORMATION AGENCY (EIA) 2013. International Energy Outlook. U.S. Department of Energy. 
VAN BEERS, D., BOSSILKOV, A., CORDER, G. \& VAN BERKEL, R. 2007. Industrial Symbiosis in the Australian Minerals Industry: The Cases of Kwinana and Gladstone. Journal of Industrial Ecology, 11, 55-72.

VAN DEN WALL BAKE, J. D., JUNGINGER, M., FAAIJ, A., POOT, T. \& WALTER, A. 2009. Explaining the experience curve: Cost reductions of Brazilian ethanol from sugarcane. Biomass and Bioenergy, 33, 644-658.

VERBRUGGEN, A., FISCHEDICK, M., MOOMAW, W., WEIR, T., NADAÏ, A., NILSSON, L. J., NYBOER, J. \& SATHAYE, J. 2010. Renewable energy costs, potentials, barriers: Conceptual issues. Energy Policy, 38, 850-861.

WALLÉN, G. 1993. Vetenskapsteori och forskningsmetodik, Studentlitteratur.

WELLISCH, M., JUNGMEIER, G., KARBOWSKI, A., PATEL, M. K. \& ROGULSKA, M. 2010. Biorefinery systems-potential contributors to sustainable innovation. Biofuels, Bioproducts and Biorefining, 4, 275-286.

WESTHOLM, E. \& BELAND LINDAHL, K. 2012. The Nordic welfare model providing energy transition? A political geography approach to the EU RES directive. Energy Policy, 50, 328-335.

WOLF, A. 2004. Devloping efficient industrial systems through increased integration - applications in the forest industry. Licentiate thesis, Linköping Institute of Technology.

WOLF, A. 2007. Industrial Symbiosis in the Swedish Forest Industry. Ph D, Linköping university.

WOLF, A. \& KARLSSON, M. 2008. Evaluating the environmental benefits of industrial symbiosis: Discussion and demonstration of a new approach. Progress in Industrial Ecology, 5, 502-517.

WORLD BANK. 2013. Transport: Sector results profile [Online]. Available: http://www.worldbank.org/en/results/2013/04/14/transport-results-profile [Accessed 12th of November 2013.

WRIGHT, R. A., CÔTÉ, R. P., DUFFY, J. \& BRAZNER, J. 2009. Diversity and Connectance in an Industrial Context. Journal of Industrial Ecology, 13, 551-564.

WRIGLEY, E. A. 1962. The Supply of Raw Materials in the Industrial Revolution. The Economic History Review, 15 1-16.

YIN, R. K. 1994. Case Study Research Design and Methods, Sage Publications. 
"On ne connaît que les choses qu'on apprivoise"

Extract from Le Petit Prince by Antoine de Saint-Exupéry 


\section{Papers}

The articles associated with this thesis have been removed for copyright reasons. For more details about these see:

http://urn.kb.se/resolve?urn=urn:nbn:se:liu:diva-106651 